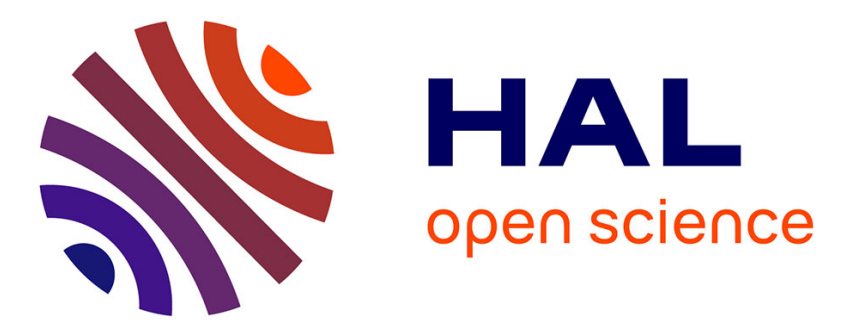

\title{
Chemical and physical erosion rhythms of the West African Cenozoic morphogenesis: The 39 Ar- 40 Ar dating of supergene K-Mn oxides
}

\author{
Anicet Beauvais, Gilles Ruffet, Olivier Hénocque, Fabrice Colin
}

\section{To cite this version:}

Anicet Beauvais, Gilles Ruffet, Olivier Hénocque, Fabrice Colin. Chemical and physical erosion rhythms of the West African Cenozoic morphogenesis: The 39 Ar- 40 Ar dating of supergene K-Mn oxides. Journal of Geophysical Research: Earth Surface, 2008, 113 (F4), pp.F04007. 10.1029/2008JF000996 . hal-01097306

\section{HAL Id: hal-01097306 \\ https://hal.science/hal-01097306}

Submitted on 20 Dec 2016

HAL is a multi-disciplinary open access archive for the deposit and dissemination of scientific research documents, whether they are published or not. The documents may come from teaching and research institutions in France or abroad, or from public or private research centers.
L'archive ouverte pluridisciplinaire HAL, est destinée au dépôt et à la diffusion de documents scientifiques de niveau recherche, publiés ou non, émanant des établissements d'enseignement et de recherche français ou étrangers, des laboratoires publics ou privés. 


\title{
Chemical and physical erosion rhythms of the West African Cenozoic morphogenesis: The ${ }^{39} \mathrm{Ar}-{ }^{40} \mathrm{Ar}$ dating of supergene K-Mn oxides
}

\author{
Anicet Beauvais, ${ }^{1}$ Gilles Ruffet, ${ }^{2}$ Olivier Hénocque, ${ }^{1}$ and Fabrice Colin $^{3}$ \\ Received 12 February 2008; revised 17 June 2008; accepted 15 August 2008; published 1 November 2008.
}

[1] Chemical weathering and mechanical erosion are first-order processes of long-term tropical morphogenesis, which is still poorly deciphered for lack of time constraints. We address this issue by laser probe ${ }^{39} \mathrm{Ar}^{40} \mathrm{Ar}$ dating of generations of cryptomelane $\left[\mathrm{K}_{1-2} \mathrm{Mn}_{8} \mathrm{O}_{16}, n \mathrm{H}_{2} \mathrm{O}\right]$ from the manganese ore deposit of Tambao in northern Burkina Faso. This Mn deposit results from the supergene weathering of carbonate and silicate Mn protores underneath lateritic palaeolandsurfaces. It consists of an upper cryptomelane-rich domain and a lower domain where pyrolusite $\left(\beta-\mathrm{MnO}_{2}\right)$ is the dominant Mn oxide. The oldest ${ }^{39} \mathrm{Ar}-{ }^{40} \mathrm{Ar}$ ages (59-45 Ma) are obtained on surface outcrops while the youngest ones characterize deep oxidation fronts (3.4-2.9 Ma). Apparent correlations of ${ }^{39} \mathrm{Ar}^{40} \mathrm{Ar}$ age groups with $\delta^{18} \mathrm{O}$ and eustatic curves allow definition of the different stages of morphogenesis. Paleocene-Eocene ages (59-45 Ma) bracket a greenhouse period propitious to bauxitic weathering. The lack of significant ages between $\sim 45$ and 29 Ma characterizes a period dominated by mechanical erosion, during which detrital sediments, including lateritic materials, were accumulated in intracratonic basins allowing the exhumation of a new lateritic landsurface. Two major weathering periods separated by a second erosion episode $(24-18 \mathrm{Ma})$ are also depicted at the end of Oligocene (29-24 Ma) and lower to mid-Miocene $(18-11.5 \mathrm{Ma})$ in the upper domain, during which newly shaped land surfaces conspicuously weathered. The shorter-weathering and erosion episodes recorded in the lower domain from $\sim 18$ to $\sim 2.9$ Ma led to the final geomorphic changes that were conducive to the formation of glacis. The preservation of old cryptomelane (59-45 Ma) in the upper part of the ore deposit indicates a Cenozoic denudation limited to the erosion of previous bauxites, and partly, of ferricretes.

Citation: Beauvais, A., G. Ruffet, O. Henocque, and F. Colin (2008), Chemical and physical erosion rhythms of the West African Cenozoic morphogenesis: The ${ }^{39} \mathrm{Ar}-{ }^{40} \mathrm{Ar}$ dating of supergene K-Mn oxides, J. Geophys. Res., 113, F04007, doi:10.1029/2008JF000996.

\section{Introduction}

[2] Most lateritic deposits and tropical soils result from long-term meteoric weathering of the lithosphere and are still widespread on the Earth surface, especially throughout the tropical belt [Pedro, 1968; Nahon, 1991]. Following Gondwana breakup, physical, and chemical processes driven by epeirogeny and climate led to the development of tens of meters of thick weathering mantles including bauxites and ferricretes, which are preserved on stepped relicts of abandoned planation surfaces and pediplains [Millot, 1983; Aleva, 1984; Bardossy and Aleva, 1990; Nahon et al.,

\footnotetext{
${ }^{1}$ Centre Européen de Recherche et d'Enseignement de Géosciences de l'Environnement, Université Aix-Marseille, CNRS, INSU, IRD, Collège de France, Aix-en-Provence, France.

${ }^{2}$ Géosciences Rennes, Université de Rennes 1, CNRS, CAREN, Rennes, France.

${ }^{3}$ Institut de Recherche pour le Développement, Nouméa, New Caledonia.

Copyright 2008 by the American Geophysical Union. 0148-0227/08/2008JF000996\$09.00
}

1992; Tardy and Roquin, 1998; Chevillotte et al., 2006]. These lateritic paleosurface relicts result from the combination of long-term weathering, incision and erosion processes [King, 1967; Partridge and Maud, 1987]. According to the synthetic morphogenetic sequence described in West Africa [Vogt, 1959; Michel, 1973; Grandin, 1976; Boulangé and Millot, 1988; Thomas, 1994], the highest surfaces carrying bauxite dominate landsurfaces with different generations of ferricrete (Figure 1). Manganese ore deposits may also develop within specific rock's weathering mantles. Below the bauxitic paleosurface, the intermediate ferricrete-capped relief dominates three pediments (Figure 1) so-called lateritic glacis in West Africa [Thomas, 1994], and defined as high, middle, and low glacis. The term glacis defines a gently inclined surface carrying detrital lateritic and bedrock materials.

[3] The age determination of the paleosurfaces and their lateritic weathering remains a critical issue in estimating the erosion rates and constraining the long-term tropical morphogenesis and the evolution of continental palaeoclimates. A relative chronology of the lateritic landsurfaces was 


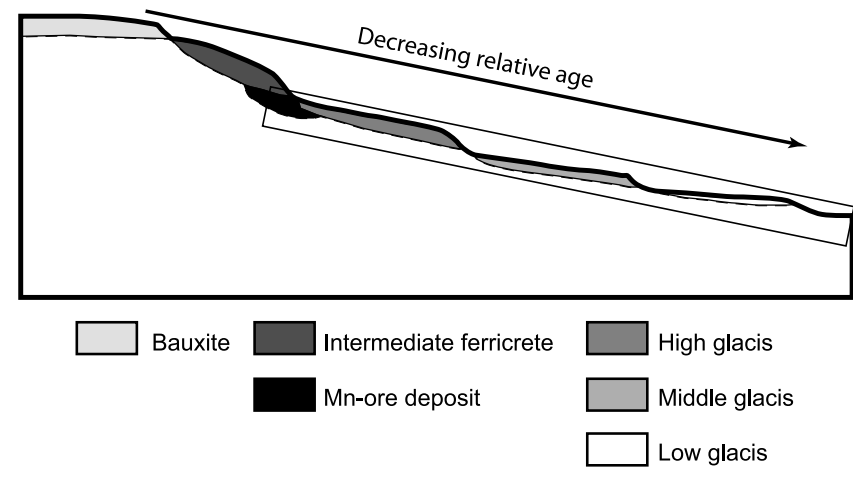

Figure 1. Synthetic geomorphological sequence of lateritic paleolandsurfaces in West Africa. The rectangle defines the Tambao sequence in North Burkina Faso.

assessed by examining the height differences between the landsurfaces and the geochemical composition of the associated lateritic materials that allowed a first estimation of the erosion rates [Tardy and Roquin, 1998]. However, betterconstrained ages of past chemical weathering and mechanical erosion periods can be obtained by performing ${ }^{39} \mathrm{Ar}^{-40} \mathrm{Ar}$ laser probe dating of K-Mn oxides in supergene manganese ore deposits that constitutes a perfect alternative to the apatite fission track approach [Gunnell, 2003] to constrain the Cenozoic cratonic denudation for different time spans.

[4] Previous geochronological studies proved the usefulness of K-Ar and ${ }^{39} \mathrm{Ar}^{40} \mathrm{Ar}$ methods to date potassium-rich supergene minerals such as cryptomelane [Vasconcelos et al., 1992, 1994; Lippolt and Hautmann, 1995; Ruffet et al., 1996; Hénocque et al., 1998]. This K-Mn oxide is believed to reflect strong lateritic weathering conditions [Parc et al., 1989], and it is ubiquitous in numerous supergene manganese ore deposits [Nahon et al., 1984; Beauvais et al., 1987; Roy, 1981, 1988; Dasgupta et al., 1992; Oswald, 1992; Pracejus and Bolton, 1992; Varentsov, 1996]. The Tambao Mn ore deposit in northern Burkina Faso is clearly integrated in the continental-scale geomorphological sequence (Figure 1) and its high-cryptomelane content [Perseil and Grandin, 1978] motivated ${ }^{39} \mathrm{Ar}-{ }^{40} \mathrm{Ar}$ geochronological investigations. ${ }^{39} \mathrm{Ar}^{40} \mathrm{Ar}$ laser method was first performed on two Mn-rich botryoidal concretions [Hénocque et al., 1998] that showed an episode of cryptomelane formation between 44.5 and $50 \mathrm{Ma}$. Later, ${ }^{39} \mathrm{Ar}-{ }^{40} \mathrm{Ar}$ age groups of 59-56, 47-44, and 27-24 Ma were obtained on seven samples of manganiferous pisolites deriving from a massive $\mathrm{Mn}$ crust [Colin et al., 2005]. These previous results allowed linking of the formation of surface Mn crusts and pisolites to the Paleogene bauxitic period. In this paper we investigate many more samples from drill cores to better characterize the successive stages of the $\mathrm{Mn}$ ore deposit formation that may usefully document the long-term (Paleogene and Neogene) morphogenesis and denudation.

\section{Material, Sampling, and Analytical Methods}

[5] Cryptomelane occurs in single or multiple generations associated with other Mn oxides [Beauvais et al., 1987]. This is the K-rich end-member of the hollandite Mn oxide group with a general formula, $\mathrm{A}_{1-2} \mathrm{~B}_{8} \mathrm{O}_{16}, \mathrm{nH}_{2} \mathrm{O}$ (with $\mathrm{A}=$ $\mathrm{K}^{+}, \mathrm{Ba}^{2+}, \mathrm{Na}^{+}, \mathrm{Pb}^{2+}$ and $\left.\mathrm{B}=\mathrm{Mn}^{4+}, \mathrm{Mn}^{2+}, \mathrm{Fe}^{3+}, \mathrm{Al}^{3+}\right)$, and a tunnel structure made by double chains of $\mathrm{MnO}_{6}$ octahedra [Burns and Burns, 1979; Turner and Buseck, 1979]. Large cations of the A site counterbalance the charge deficit due to the $\mathrm{Mn}$ oxidation states and the other cations of the $\mathrm{B}$ site. The cryptomelane structure increases its potassium and argon retentiveness, and thus its suitability for K-Ar and ${ }^{39} \mathrm{Ar}^{40} \mathrm{Ar}$ geochronological investigations [Vasconcelos et al., 1992, 1994].

[6] The first applications of the K-Ar dating method to cryptomelane were very promising despite problems of phase mixing and difficulties for extracting pure samples [Chukhrov et al., 1966; Yashvili and Gukasyan, 1974; Varentsov and Golovin, 1987; Segev et al., 1991]. The small quantities required for ${ }^{39} \mathrm{Ar}-{ }^{40} \mathrm{Ar}$ laser probe dating reduce the mixing risks [Ruffet et al., 1996], which are further lessened by a precise sampling [Hénocque et al., 1998].

\subsection{Petrography and Mineralogy}

[7] Samples were taken from drill cores DD2B, DDH76-02 and DDH76-09 of 110 and 40-m length, respectively (Figures 2 and 3) and from outcrops of manganese oxide benches. DD2B, DDH76-02 and DDH76-09 cores were drilled on the high and low hills (Figure 2). The altitude of samples in the cores and at the surface of the deposit is calculated to allow comparisons and to define relations with landsurface processes.

[8] Polished thin sections of samples were observed with an optical microscope (Leica DMRXP) while scanning electron microscopy (SEM) was used for subsample investigations. Manganese oxides were characterized by X-ray diffraction, using a Philips PW 1710 diffractometer with a $\mathrm{Cu}$ tube anode $(\mathrm{k} \alpha 1=1.78896 ; \mathrm{k} \alpha 2=1.79285)$ to avoid fluorescence effects. Major chemical elements were measured out using ICP-OES.

[9] When several cryptomelane generations occurred in a same sample, subsamples were extracted and identified with a capital letter (BF96-327-A and BF96-327-B) or a twodigit number $(01,02,03$, etc). The subsamples selected for ${ }^{39} \mathrm{Ar}-{ }^{40} \mathrm{Ar}$ dating were labeled with a small letter added to the sample number (e.g., BF96-632-a1 and BF96-632-f2).

\subsection{The ${ }^{39} \mathrm{Ar}^{40} \mathrm{Ar}$ Analysis}

[10] Samples selected for ${ }^{39} \mathrm{Ar}^{40} \mathrm{Ar}$ dating were hand picked from $0.5 \mathrm{~mm}$ thin slabs cut from petrographic samples. They were wrapped in aluminum foil to form small packets, which were stacked into a column within which packets of flux monitors were inserted every 8 to 10 samples. This configuration allows determination of the vertical flux gradient with a precision as low as $\pm 0.2 \%$. Samples were irradiated in the $5 \mathrm{C}$ position of the McMaster reactor (Hamilton, Canada) together with biotite monitor Bern4B (17.25 Ma) [Hall et al., 1984], with amphibole monitor Zartman Hb3gr (1072 Ma) [Zartman, 1964; Turner, 1971; Roddick, 1983], or with sanidine monitor Draz (24.99 Ma) [Wijbrans et al., 1995]. Because the sample age was unknown, 4 to $70 \mathrm{~h}$ irradiations were tested [Hénocque et al., 1998], $25 \mathrm{~h}$ being the most suitable.

[11] A VG 3600 mass spectrometer equipped with a Daly ${ }^{10}$ detector was used for analyses. Each static mea- 


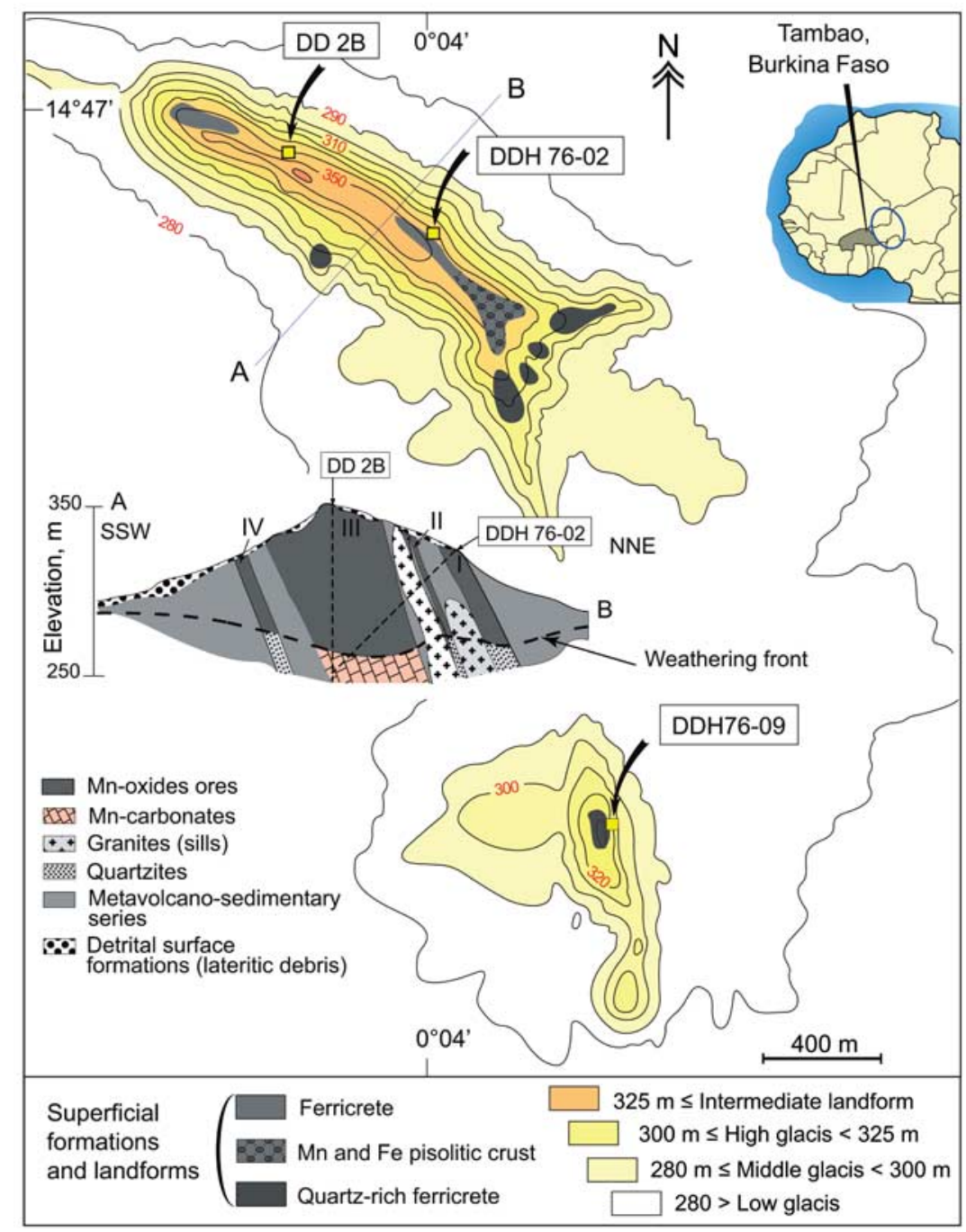

Figure 2. Location and geomorphologic patterns of the Mn ore deposit of Tambao in North Burkina Faso, with the locations of the drill cores, and a section (A-B line) across the main geological formations. The blue circle in the inset is the intracratonic sedimentary basin.

surement of argon isotopes corresponds to 11 peak hopping scans. Backgrounds of the extraction and purification line were measured every first or third step and subtracted from each argon isotope of the subsequent gas fractions. Typical blank values were included in the ranges $3.2 \times 10^{-12}<\mathrm{M} / \mathrm{e} 40<4.8 \times 10^{-13}, 7.4 \times$ $10^{-14}<\mathrm{M} / \mathrm{e} 39<4.6 \times 10^{-15}, 6.6 \times 10^{-14}<\mathrm{M} / \mathrm{e} 38<$ $3.5 \times 10^{-16}, 1.3 \times 10^{-13}<\mathrm{M} / \mathrm{e} 37<1.7 \times 10^{-14}$ and $7.6 \times 10^{-14}<\mathrm{M} / \mathrm{e} 36<2.1 \times 10^{-15} \mathrm{~cm}^{3}$ STP. All isotopic measurements were corrected for $\mathrm{K}, \mathrm{Ca}$, and $\mathrm{Cl}$ isotopic interferences, mass discrimination and atmospheric argon contaminations. Three consecutive steps accounting for $70 \%$ of the total ${ }^{39} \mathrm{Ar}$ released define a plateau age and the individual age fractions must agree within $2 \sigma$ error bars of the "integrated" age of the plateau segment. Pseudoplateau ages can be calculated, however, with less than $70 \%$ of the ${ }^{39} \mathrm{Ar}_{\mathrm{K}}$ released. All errors are quoted at the $1 \sigma$ level and do not account for ${ }^{40} \mathrm{Ar}^{*} /{ }^{39} \mathrm{Ar}_{\mathrm{K}}$ ratio and monitor age uncertainty, which is included in the calculation of the plateau age error.

\section{Geographical, Geomorphological, and Geological Setting}

[12] The Tambao Mn ore deposit is located in North Burkina Faso $\left(14^{\circ} 47 \mathrm{~N}, 0^{\circ} 04 \mathrm{E}\right)$ in the subsahelian area close to a continental sedimentary basin (Figure 2). The mean annual rainfall is $375 \mathrm{~mm}$. The vegetation is composed of a grassy steppe alternating with forest patches along river drainage axes. The Mn ore deposit is composed of two hills corresponding to lateritic landsurface relicts.

\subsection{Distribution and Characterization of Lateritic Landsurfaces}

[13] Four major landsurfaces are observed around Tambao (Figures 1 and 2). The highest one is identified on the high hill between 353 and $325 \mathrm{~m}$ elevation corresponding to 


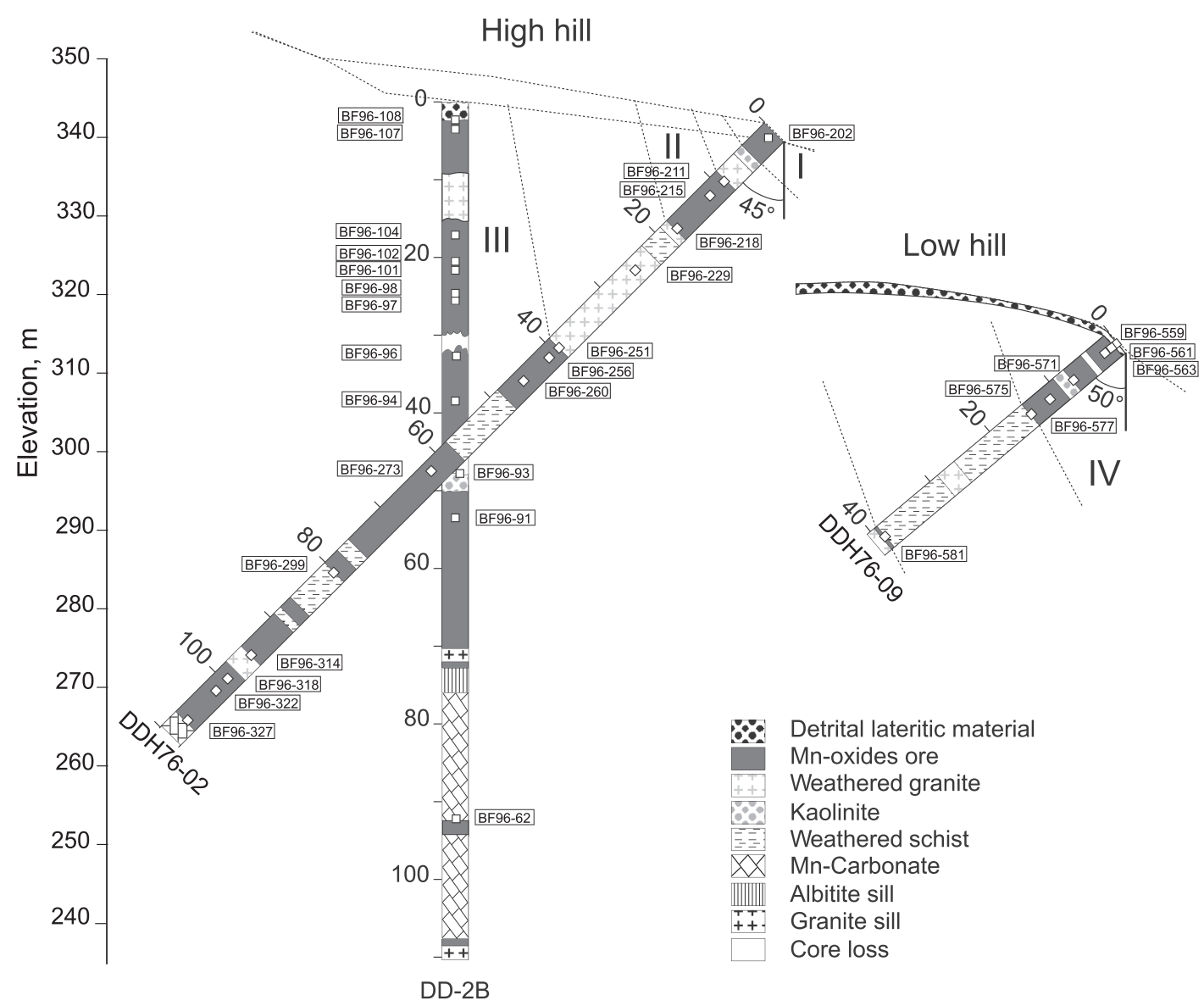

Figure 3. Logs of the drill cores with the locations of samples dated by the ${ }^{39} \mathrm{Ar}-{ }^{40} \mathrm{Ar}$ method.

a relict of the intermediate landsurface [Grandin, 1976], which bears ferricrete and/or Fe-Mn and Mn pisolitic crusts [Colin et al., 2005]. The second landsurface observed between 325 and $300 \mathrm{~m}$ on the highest hillslope corresponds to the high glacis, which is characterized by a quartzose ferricrete incorporating reworked manganiferous and ferruginous pebbles originating from the upper landsurface. The low hill also shows intermediate $\mathrm{Fe}-\mathrm{Mn}$ crust relicts, the high glacis being mainly represented between 325 and $300 \mathrm{~m}$ with a quartzose ferricrete (Figure 2). Two lower landsurfaces are observed in the surrounding plain at about $300-280 \mathrm{~m}$ and $<280 \mathrm{~m}$ corresponding to the middle and low glacis, respectively. The former bears a ferricrete, while the second is a sandy erosion surface.

\subsection{Parent Rocks and Protores}

[14] Long-term lateritic weathering of a complex parent rocks assemblage has produced a 70 to $80 \mathrm{~m}$ thick supergene manganese ore deposit (Figures 2 and 3). The Tambao Mn deposit hosts a reserve of about $15 \mathrm{Mt}$ of manganese ore with an $\mathrm{MnO}$ content of $75 \mathrm{wt} \%$ [Boulanger and Sanguinetti, 1970]. Four layers of manganese ores developed from weathered Birimian (Paleoproterozoic age) metavolcanic and metasedimentary rocks (Figure 2), composed of schist, micaschist, tuff, carbonate and quartzite [Grandin, 1976; J. Delfour, Géologie du gîte de manganèse de Tambao (HauteVolta), unpublished report, 1963]. Metamorphism of the
Birimian rocks is related to syntectonic and posttectonic granite and granodiorite intrusions [Picot and Trinquard, 1969]. The metamorphic carbonates and tuffs are the main protores of the Mn deposit reflecting the mining quality of the ore [Boulanger and Sanguinetti, 1970; D. N. Collins et al., The treatment of Tambao manganese ore deposit for United Nations, unpublished report, 1971], which consists of a high-grade carbonate ore with hausmannite $\left(\mathrm{Mn}_{3} \mathrm{O}_{4}\right)$, a rhodochrosite-rich carbonate ore and a low-grade carbonate ore containing kutnahorite $\left([\mathrm{Ca}, \mathrm{Mg}, \mathrm{Mn}] \mathrm{CO}_{3}\right.$ ). About $70 \%$ of the Mn ore derives from the weathering of rhodochrosite (Figure 3) [Picot and Trinquard, 1969] and $30 \%$ from the weathering of spessartine-rich quartzite [Perseil and Grandin, 1978].

\section{Weathering and Oxidation of Protores 4.1. Petrography}

[15] In drill core DD2B, at altitudes ranging from 241 and $265 \mathrm{~m}$ (Figure 3), the parent rock is a very heterogeneous carbonate protore characterized by a ribbon pink carbonate matrix embedding thin beds $(0.1-1 \mathrm{~m}$ thick) of manganese oxides grains, which preserve the ribbon structure. The transition between the protore and the oxidized $\mathrm{Mn}$ ore is thin and partly masked by a small albitite sill in drill DD-2B (Figure 3). Between 270 and $345 \mathrm{~m}$ (Figure 3), the parent rock is directly replaced by the oxidized manganese ore 
(a)

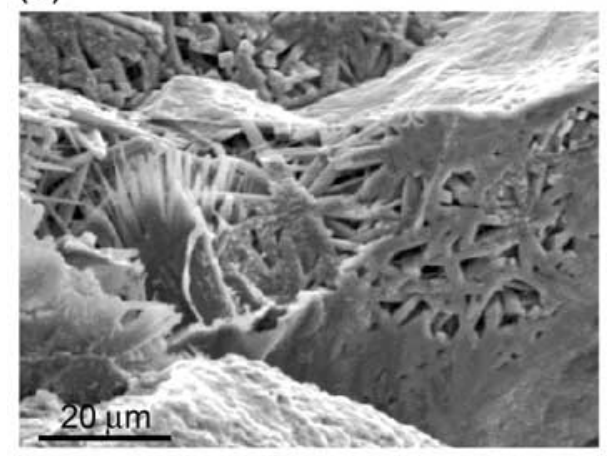

(b)

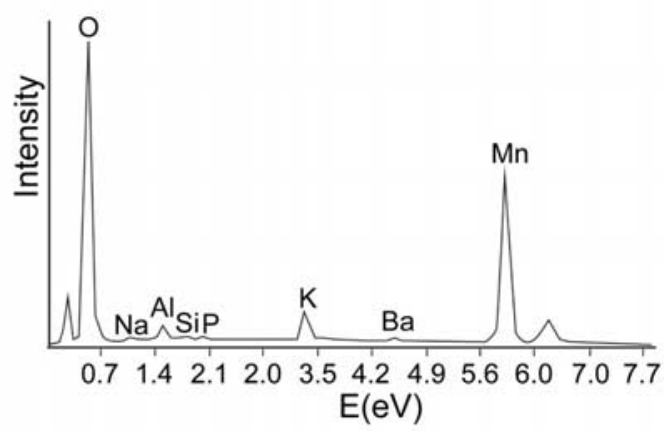

Figure 4. (a) SEM photomicrograph of cryptomelane needles with (b) its chemical analysis.

(layer III), which also partially preserves primary structures (folds and schistosity). The top of the core (345 m) is mostly composed of detrital lateritic material. The drill core also cut across more or less weathered granite and kaolinite-rich layers between 275 and $335 \mathrm{~m}$ (Figure 3). The oxidation of the manganese carbonate protore induced a large porosity in which botryoidal manganese oxide aggregates developed [Hénocque et al., 1998].

[16] The drill core DDH76-02 allows exploration of layers I, II and III (Figure 3). The parent rock was not reached by the drill core but could be directly observed from outcrops. Successions of manganese-rich and manganese-poor layers (10 $\mathrm{cm}$ thick) characterize the quartzite formation. The manganese oxides layers deriving from the weathering of Mn-garnet- (spessartine) -rich quartzite are thinner. Between 270 and $350 \mathrm{~m}$, the manganese oxides present various aspects, porous and light and/or massive and heavy with many botryoidal concretions. In this core, manganese oxide layers alternate with weathered schist between 280 and $285 \mathrm{~m}, 300$ and $310 \mathrm{~m}$, and at $330 \mathrm{~m}$, and with weathered granite between 315 and $325 \mathrm{~m}$ and at $340 \mathrm{~m}$, occurring as a quartz-rich kaolinitic saprolite (Figure 3). The drill core DDH76-09 allows investigation of layer IV, between 305 and $315 \mathrm{~m}$, the lower part of the core being composed of weathered schist between 290 and 305 m (Figure 3).

\subsection{Mineralogy and Bulk Chemistry}

[17] Rhodochrosite $\left(\mathrm{MnCO}_{3}\right)$ and/or kutnahorite $\left(\mathrm{CaMn}\left(\mathrm{CO}_{3}\right)_{2}\right)$ are the predominant primary minerals of the carbonate protore, with small amounts of opaque minerals such as hausmanite $\left(\mathrm{Mn}^{2+} \mathrm{Mn}^{3+}{ }_{2} \mathrm{O}_{4}\right)$ and hetaerolite $\left(\mathrm{ZnMn}_{2} \mathrm{O}_{4}\right)$, aligned parallel to the rock schistosity. Transmitted light microscopy also reveals tephroite $\left(\mathrm{Mn}_{2} \mathrm{SiO}_{4}\right)$ and rhodonite $\left(\mathrm{MnSiO}_{3}\right)$, which are also oriented parallel to the rock schistosity. The weathering is characterized by in situ transformation of rhodochrosite, hausmannite and tephroite into manganite $(\mathrm{MnOOH})$, todorokite $\left(\left[\mathrm{Mn}^{2+}\right.\right.$, $\left.\mathrm{Mg}, \mathrm{Ca}, \mathrm{Ba}, \mathrm{Na}, \mathrm{K}]_{2}\left[\mathrm{Mn}^{4+}, \mathrm{Mn}^{3+}\right]_{7} \mathrm{O}_{12} \cdot 3 \mathrm{H}_{2} \mathrm{O}\right)$, and pyrolusite $\left(\beta-\mathrm{MnO}_{2}\right)$, while spessartine $\left(\mathrm{Mn}_{3} \mathrm{Al}_{2}\left[\mathrm{SiO}_{4}\right]_{3}\right)$ and rhodonite weathered into lithiophorite $\left([\mathrm{Al}, \mathrm{Li}] \mathrm{MnO}_{2}[\mathrm{OH}]_{2}\right)$.

[18] The manganese oxide ore of layer II developed according to three stages. Spessartine was replaced by lithiophorite. The voids resulting from the dissolution of quartz, kaolinite and pyrolusite are filled with cryptocrystalline cryptomelane. The manganese oxides were trans-

\section{(a)}

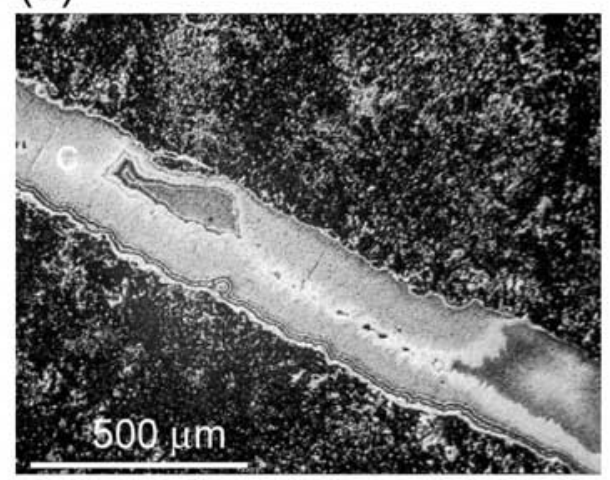

(b)

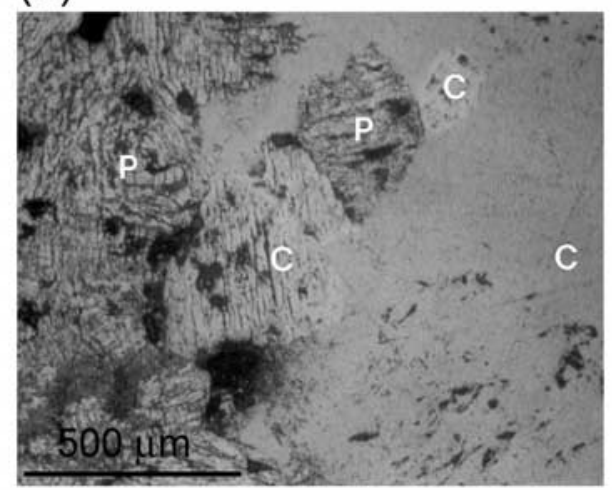

(c)

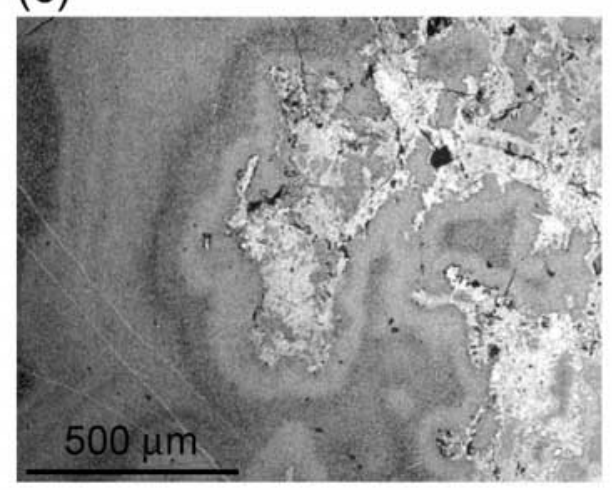

Figure 5. Photomicrographs of (a) cryptomelane (C) vein, (b) cryptomelane (C) developing from the metasomatism of pyrolusiste $(\mathrm{P})$, and (c) botryoidal cryptomelane. 


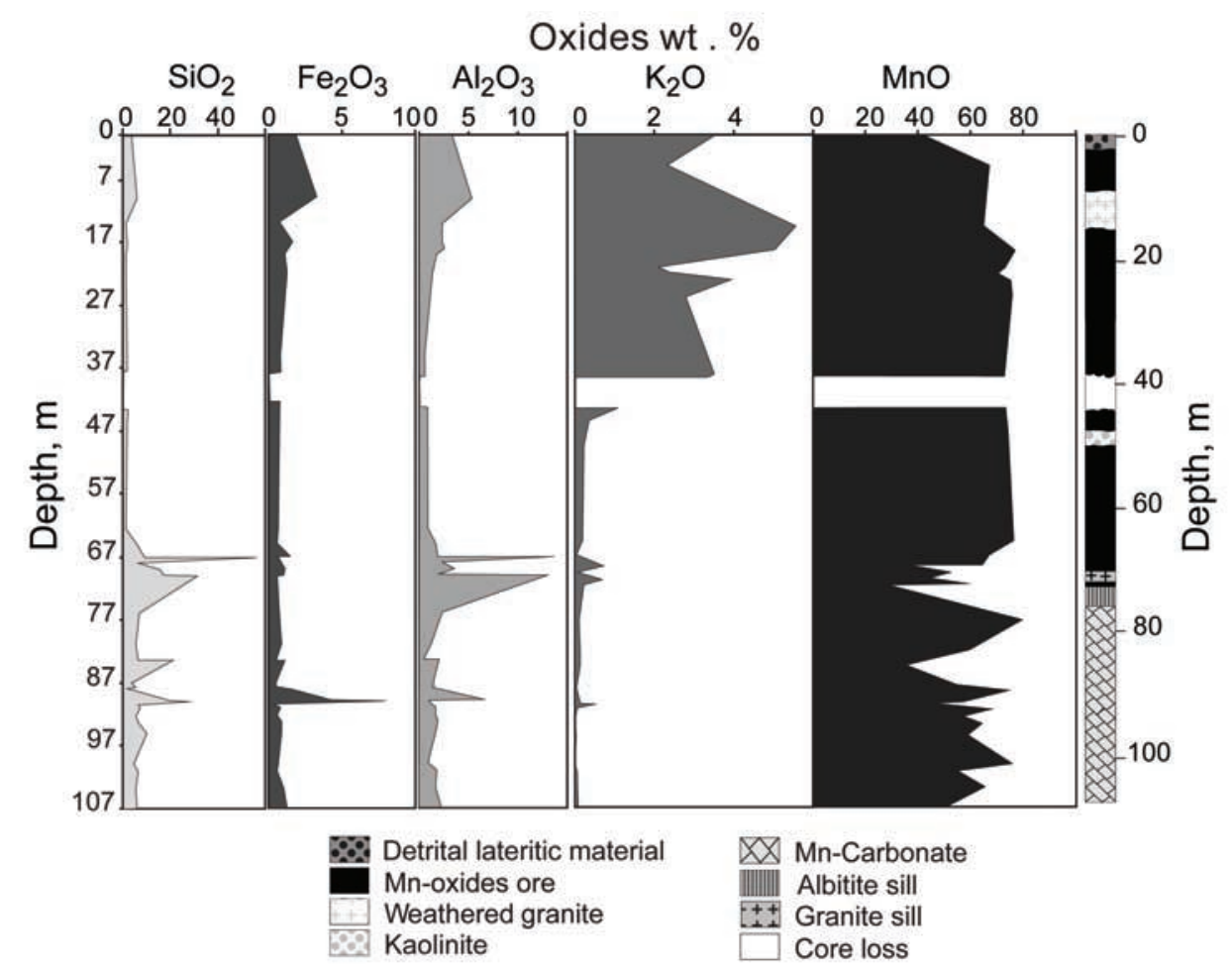

Figure 6. Geochemical evolution along DD2B drill core.

formed into well-crystallized thin needles of cryptomelane (Figure 4).

[19] The weathering of the carbonate protore leads to the formation of manganite, pyrolusite and nsutite $\left(\gamma-\mathrm{MnO}_{2}\right)$ associated with todorokite. During a first weathering stage cryptomelane occurs only in small veinlets (Figure 5a). Pyrolusite exhibits large prismatic crystals with a characteristic fracture pattern. It is transformed into cryptomelane matrices in the upper part of the deposit (Figure 5b) as indicated by the increase of $\mathrm{K}_{2} \mathrm{O}$ (Figure 6). Multiple cryptomelane generations also occur into botryoidal aggregates (Figure 5c).

\subsection{Potassium Sources for Cryptomelane}

[20] Because the Mn protores do not contain much potassium (Figure 6), sources of potassium are found in the surrounding rocks of the basement and the metavolcanic and metasedimentary rocks of the Birimian Supergroup (schists, granites, granodiorites and migmatites). Large amounts of potassium can be also trapped with clay organic molecules and also into detrital minerals like illite and micas in the upper soil horizons. The release of potassium in $\mathrm{Mn}^{2+}$-rich solutions during the weathering of $\mathrm{K}$ phyllosilicates into kaolinite can contribute to the formation of cryptomelane [Parc et al., 1989]. The depletion of Mn and $\mathrm{K}$ from the upper part of the deposit was also observed during the late transformation of the massive Mn crust into pisolitic formation, this process being contemporaneous of the major Eocene bauxitic period [Colin et al., 2005]. Bauxites in the tropics formed under humid climate with a dense vegetation cover that suggests high amounts of organic acids in solutions, which can dissolve $\mathrm{K}$ phyllosilicates and previously formed $\mathrm{Mn}$ and K-Mn oxides, with the release of $\mathrm{K}$ and Mn contributing to new cryptomelane growth in oxygenated zones of the deposit.

\section{Geochronological Investigation}

\subsection{The ${ }^{39} \mathrm{Ar}-{ }^{40} \mathrm{Ar}$ Age Spectra Configurations}

[21] The stability of the K-Ar isotopic system within cryptomelane structure mainly depends on geochemical interactions with fluids. The retentivity of argon and potassium isotopes in cryptomelane has been investigated [Lippolt and Hautmann, 1995; Vasconcelos et al., 1995; Vasconcelos, 1999]. The various configurations of the age spectra obtained during ${ }^{39} \mathrm{Ar}-{ }^{40} \mathrm{Ar}$ analyses have been discussed [Vasconcelos et al., 1995; Ruffet et al., 1996; Hénocque et al., 1998; Hautmann and Lippolt, 2000] that allowed definition of three types of age spectra improving the ${ }^{39} \mathrm{Ar}-{ }^{40} \mathrm{Ar}$ data interpretations.

[22] Type 1 "staircase" age spectra are characterized by a rapid increase of the ages in the low temperature steps followed by a rather flat segment that allows definition of a plateau age (Figure 7a). These age spectra, however, suggest ${ }^{40} \mathrm{Ar}^{*}$ losses linked to a younger weathering "episode" that could have altered the peripheral intra crystalline retention sites or induced secondary growth.

[23] Type 2 "hump shape" age spectra often show concordant "young" ages in the low and high temperature steps and "old" ages in the intermediate degassing temperatures (Figure $7 \mathrm{~b}$ ) indicating mixing of different manganese oxide generations. The low and high temperature ages are maximum estimates of the youngest generation true age, whereas the intermediate temperature ages are underestimates of the oldest generation true age. 
(a)

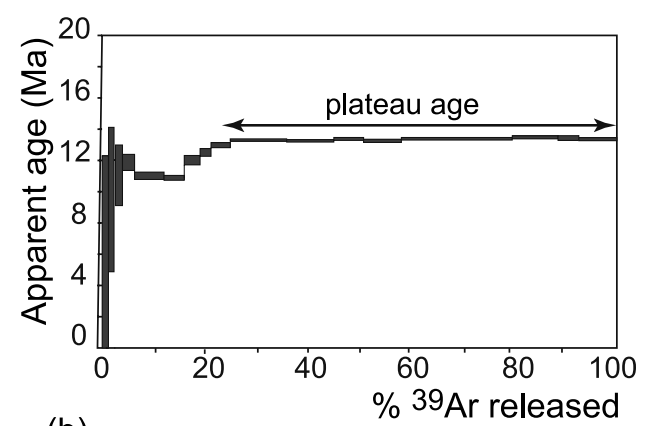

(b)

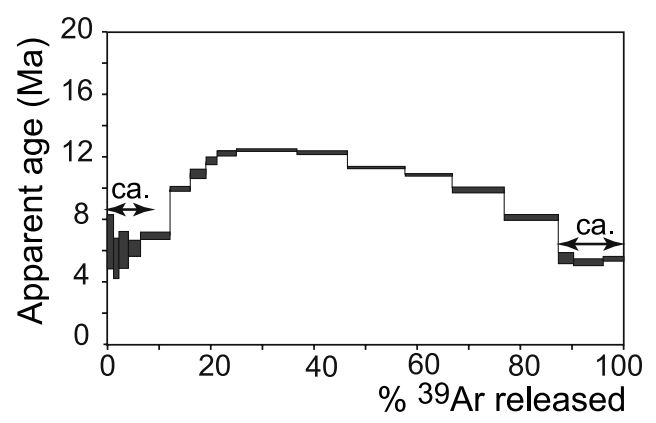

(c)

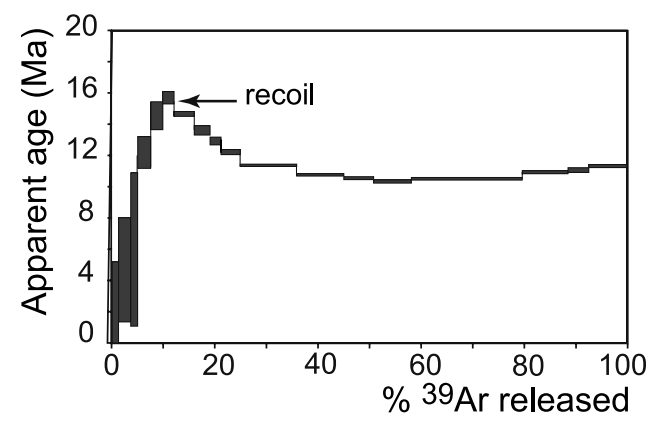

Figure 7. The ${ }^{39} \mathrm{Ar}-{ }^{40} \mathrm{Ar}$ age spectra configuration for (a) Type 1 (staircase), (b) Type 2 (hump), and (c) Type 3 shapes. (Here ca is the concordant apparent ages.)

[24] Type 3 age spectra exhibit an irregular shape with a "staircase" in the low temperature steps, the ages reaching a "maximum" followed by a decrease in the second part of the spectra up to the fusion of the mineral (Figure 7c). Mixing of different mineral generations or ${ }^{39} \mathrm{Ar}$ recoil during irradiation complicate the interpretation of these age spectra [Turner and Cadogan, 1974], although apparently significant ages can be often obtained.

\subsection{The ${ }^{39} \mathrm{Ar}^{40} \mathrm{Ar}$ Results}

[25] The results were subdivided into three groups according to the altitude of the cryptomelane samples (Figures 8, 9, and 10). ${ }^{39} \mathrm{Ar}^{40} \mathrm{Ar}$ runs are available as Data Set S1 in the auxiliary material. ${ }^{1}$

\subsubsection{First Group of Age Spectra}

[26] The first group of age spectra corresponds to cryptomelane samples taken between the groundsurface and $-17 \mathrm{~m}$ depth, i.e., between altitudes of 342 to $325 \mathrm{~m}$ that

${ }^{1}$ Auxiliary materials are available at $\mathrm{ftp} / / / \mathrm{ftp}$.agu.org/apend/jf/ 2008jf000996. are included within the topographic boundaries of the intermediate landsurface (Figures 2 and 3). Fourteen age spectra obtained on ten samples exhibit four Type 1 (staircase) and nine Type 2 (hump) shapes (Figure 8). The oldest apparent ages ( $\geq 43 \mathrm{Ma}$ ) are obtained for outcrops samples Col3 and BF96-190 (Figure 8a). Col3 was taken from outcropping layer III, at an altitude of $325 \mathrm{~m}$, on the northeastern slopes of the high hill. This sample is part of a cryptomelane vein crossing a pyrolusite ore, similar to the ones developed at the transition between pyrolusite and cryptomelane domains in the drill core DD2B (Figure 6). BF96-190 corresponds to the transition (at an altitude of $345 \mathrm{~m}$ ) between the massive ore (Layer III) and the pisolitic crusts [Colin et al., 2005] and it is the oldest one with a pseudo plateau age at $59.0 \pm 0.1 \mathrm{Ma}\left(45.2 \%{ }^{39} \mathrm{Ar}\right.$ released). The age spectrum, however, exhibits a staircase shape with low temperature apparent ages at $\sim 46.5 \mathrm{Ma}$ indicating apparent ${ }^{40} \mathrm{Ar}^{*}$ loss due to peripheral perturbations and/or growth of a younger cryptomelane generation.

[27] The four subsamples of Col3 (b to e) are characterized by hump-shaped age spectra (Figure 8a). Col3b and Col3e show the oldest pseudo plateau ages at $48.9 \pm 0.1$ and $49.9 \pm 0.2 \mathrm{Ma}$, respectively. Col3c shows a pseudoplateau age at $44.9 \pm 0.3 \mathrm{Ma}$, and Col3d is characterized by an apparent age at $46.3 \pm 0.2 \mathrm{Ma}\left(58 \%{ }^{39} \mathrm{Ar}\right.$ released $)$. The spectra show "maximum ages" as young as the magnitude of the hump is high that could indicate a mixing of two cryptomelane generations. The ages $(\sim 45-50 \mathrm{Ma})$ for Col3 are, however, concordant with the ones previously obtained for two cryptomelane concretions [Hénocque et al., 1998].

[28] Drill core samples yield systematically younger ages than outcrop and surface samples (Figures $8 \mathrm{~b}$ and $8 \mathrm{c}$ ). Samples BF96-202c3, 211, 215, and 218-a of the upper part of drill core DDH-76-02 $(342-330 \mathrm{~m})$ are characterized by hump shaped age spectra with maximum apparent ages between 34 and $40 \mathrm{Ma}$ in the intermediate temperature steps (Figure 8b). BF96-218a and 215 exhibit small concordant pseudoplateau ages in the low temperature steps at $24.6 \pm 0.8$ and $24.1 \pm 1.2 \mathrm{Ma}$, respectively (Figure 8b). BF96-229 is a small cryptomelane vein in the weathered granite between layers II and III in drill core DDH-76-02 $(326 \mathrm{~m})$ and it displays a plateau age at $17.8 \pm 0.1 \mathrm{Ma}$ with $64.1 \%{ }^{39} \mathrm{Ar}$ released (Figure $8 \mathrm{~b}$ ). The staircase age spectrum of sample BF96-104 (327 m in Drill core DD2B) also allows definition of a plateau age at $17.4 \pm 0.2 \mathrm{Ma}$ with $87 \%{ }^{39} \mathrm{Ar}$ released (Figure 8c). Age spectra of samples BF96-107 and BF96-108a (upper part of drill core DD-2B) display "old" and "young" apparent ages in the low to intermediate temperature steps at $25.6 \pm 0.4$ $\left(20 \%\right.$ of the total ${ }^{39} \mathrm{Ar}$ released) and $17.7 \pm 0.4 \mathrm{Ma}(23 \%$ of the total ${ }^{39} \mathrm{Ar}$ released), respectively, which are nearly concordant with the fusion step apparent age (Figure 8c). The age-frequency diagram (Figure $8 \mathrm{~d}$ ) reveals three major age intervals, 35-50, 23-27, and 15-18 Ma.

\subsubsection{Second Group of Age Spectra}

[29] The second group of age spectra consists of samples taken at depths ranging from -18 to $-42 \mathrm{~m}$ that correspond to the lower part of the cryptomelane domain at altitudes of 324 to $300 \mathrm{~m}$ (Figure 3), i.e., the topographic boundaries of the high glacis landsurface (Figure 2). This group of 19 samples (Figure 9) shows 24 age spectra with 6 Type 1 (staircase) shapes, 17 Type 2 (hump) shapes, and 1 Type 3 


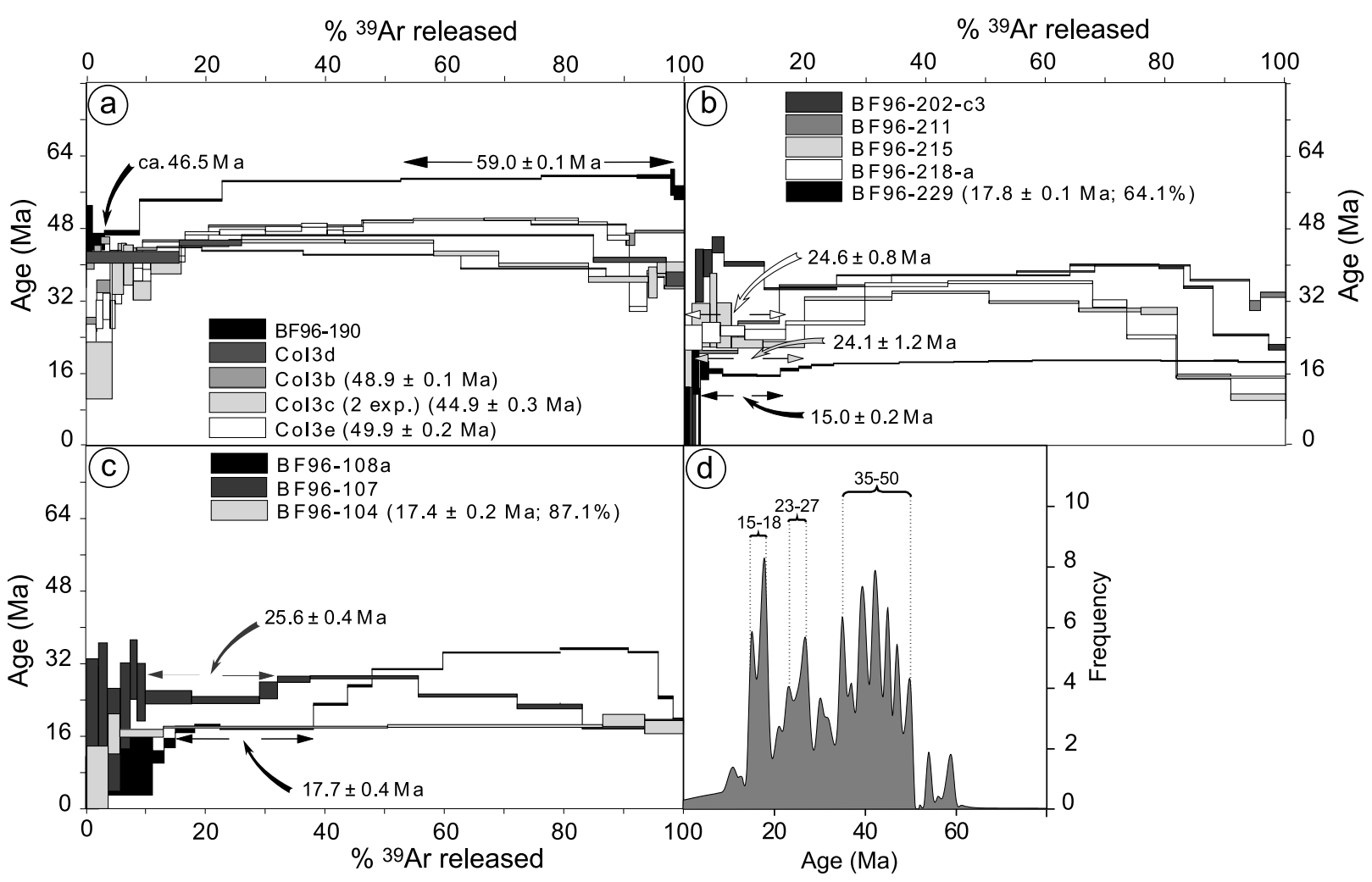

Figure 8. The ${ }^{39} \mathrm{Ar}^{-40} \mathrm{Ar}$ age spectra of cyptomelane extracted from the upper part of the deposit (342$325 \mathrm{~m}$ altitudes) for (a) outcrop and intermediate surface samples, (b) DDH76-02 drill core, (c) DD2B drill core, and (d) frequency diagram of apparent ages. (See Figure 3 for sample locations.)

shape (BF96-101-b2). Samples of the high hill cores (DD2B and DDH76-02) were taken within the layer III between 325 and $320 \mathrm{~m}$ (BF96-97, 98, 101 and 102) and between 315 and $300 \mathrm{~m}$ (BF96-251, 256, 96, 260, 94, and 273). Samples of the low hill core were taken between 315 and $313 \mathrm{~m}$ (BF96-559, 561, and 563) and between 309 and $300 \mathrm{~m}$ (BF96-571-02, 575-b, and 577) (Figure 3). Sample Col1 and BF93-632-f2 are outcrop and surface sample, at altitudes of 320 and $307 \mathrm{~m}$, respectively.

[30] Col1 is cryptomelane developing from metasomatism of pyrolusite (Figure 5b). Coll duplicates irradiated for 5 and $70 \mathrm{~h}$ yielded very similar hump shape age spectra (Figure 9a) indicating no ${ }^{39} \mathrm{Ar}$ recoil during irradiation. The two age spectra show nearly concordant maximum ages in the range $45.3 \pm 0.4$ to $44.4 \pm 0.1 \mathrm{Ma}$ while one obviously shows a small pseudoplateau age at $27.3 \pm 0.7 \mathrm{Ma}$ derived from six concordant steps at low temperature (5 to $15 \%$ of the total ${ }^{39} \mathrm{Ar}$ released) that is also concordant with high temperature ages (Figure 9a). BF96-632 is a hollandite concretion sampled underneath the high glacis ferricrete at an altitude of $307 \mathrm{~m}$. A subsample (BF96-632-a1) yields an interesting hump-shaped age spectrum with concordant low and high temperature ages at $\sim 16 \mathrm{Ma}$ (Figure 9a). A second subsample (BF96-632-f2) is characterized by a staircase age spectrum with low temperature ages at $\sim 16 \mathrm{Ma}$ (Figure $9 \mathrm{a}$ ), and an intermediate to high temperature pseudoplateau age at $36.2 \pm 0.2 \mathrm{Ma}\left(46.3 \%\right.$ of the total ${ }^{39} \mathrm{Ar}$ released).

[31] Samples of DD2B core are characterized by plateau ages calculated from staircase and hump-shaped age spectra around 24 (Figure 9b) and at $14.9 \pm 0.1$ and $17.1 \pm 0.1 \mathrm{Ma}$
(Figure 9c). An older plateau age was also calculated at $28.8 \pm 0.1 \mathrm{Ma}$ (BF96-251) while four younger plateau ages are evident between $11.5 \pm 0.2$ and $14.6 \pm 0.3 \mathrm{Ma}$ for DD76-02 core samples (Figure 9d). Sample BF96-260 with younger apparent ages $(\sim 21-22 \mathrm{Ma})$ exhibits a clear hump shape that does not allow plateau age calculation (Figure 9d).

[32] Samples of DDH76-09 core provided plateau ages at $27.1 \pm 0.3$ and two younger at $\sim 24-25 \mathrm{Ma}$ (Figure 9e). One sample (BF96-577) at an altitude of $304 \mathrm{~m}$ is characterized by a unique "older" age at $36.3 \mathrm{Ma}$ (Figure 9f) that is comparable with the intermediate to high temperature age of BF96-632-f2 (Figure 8a). The age frequency diagram reveals four age and/or age intervals, 12.5, 14-17, 2125 , and 27-29 Ma (Figure 9g) all being concordant with objectively calculated pseudoplateau and plateau ages.

\subsubsection{Third Group of Age Spectra}

[33] The third group of age spectra consists of samples mainly taken from the pyrolusite-rich core (BF96-62, 91, $93,299,314,318,322,327,581$, and 653) between depths of $-42 \mathrm{~m}$ to $-89 \mathrm{~m}$ corresponding to altitudes of $300-253 \mathrm{~m}$, which are also the topographic ranges of the two lowest glacis (Figures 2 and 3). BF96-62 is a thin cryptomelane rim around a small pyrolusite concretion in the carbonate protore of DD2B core. Sample BF96-653 is a fragment of a cryptomelane vein crossing the exhumed schist saprolite of the low glacis. This third group includes 11 age spectra with five staircase and six hump shapes that allowed the calculation of seven pseudoplateau ages lower than $20 \mathrm{Ma}$ (Figure 10). 

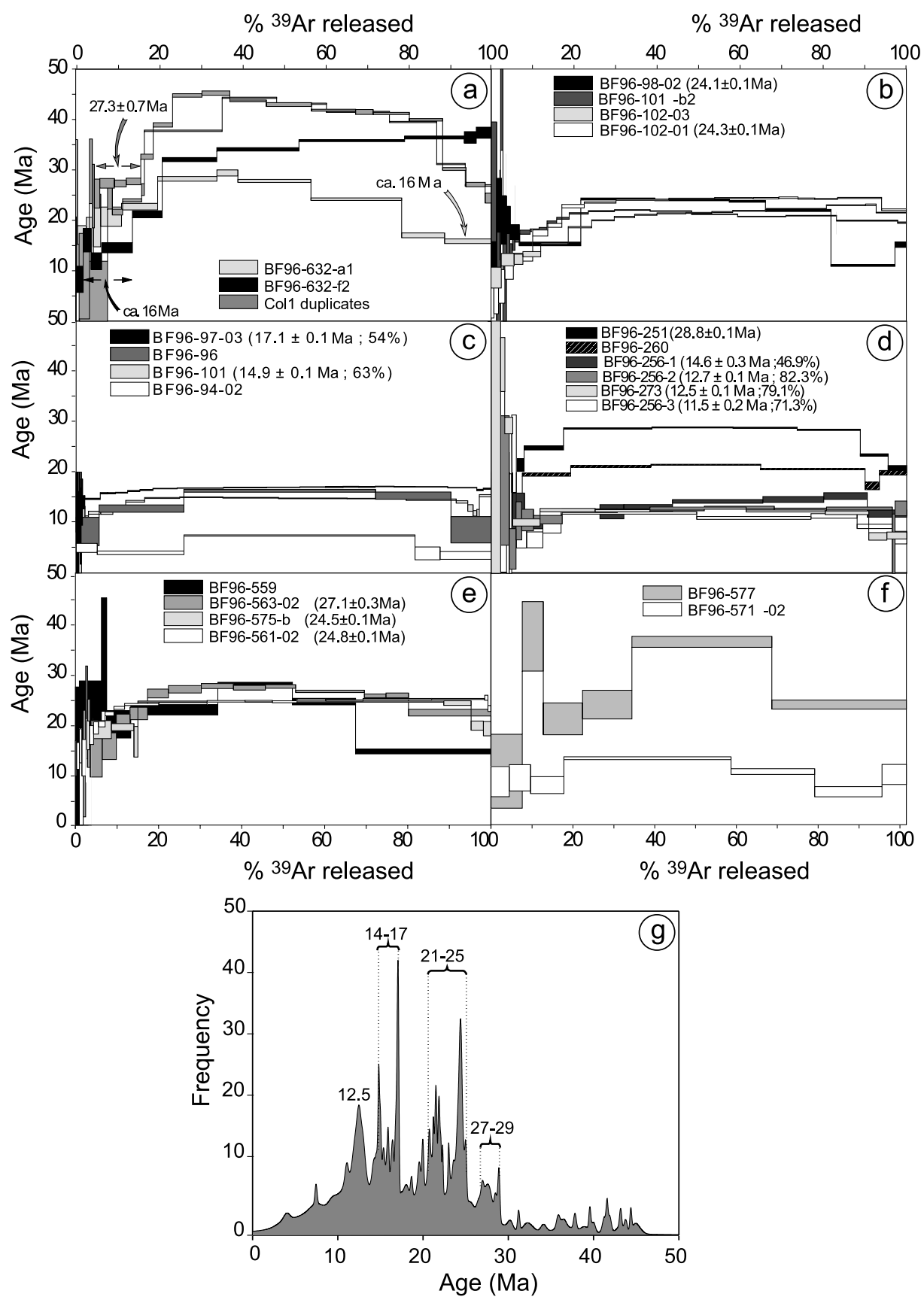

Figure 9. The ${ }^{39} \mathrm{Ar}-{ }^{40} \mathrm{Ar}$ age spectra of cyptomelane extracted from the upper and middle parts of the deposit (325-300 m altitudes) for (a) outcrop samples, (b and c) DD2B drill core, (d) DDH76-02 drill core, (e and f) DDH76-09 drill core, and (g) frequency diagram of apparent ages. (See Figure 3 for sample locations.)

[34] Large error bars shown by some age spectra (BF9662-03, BF96-91, and BF96-322) characterize the very low $\mathrm{K}_{2} \mathrm{O}$ content of these samples (e.g., $0.2 \mathrm{wt} \%$ for BF96-91). Samples BF96-93 and BF96-299 of the high hill cores display plateau ages at $11.5 \pm 0.1$ and $18.3 \pm 0.3 \mathrm{Ma}$, respectively (Figures $10 \mathrm{a}$ and $10 \mathrm{~b}$ ). The age spectrum of BF96-581 at $293 \mathrm{~m}$ altitude yields older apparent ages at $\sim 24 \mathrm{Ma}$, which are concordant with the plateau ages obtained upper for samples BF96-561-02, 563-02, and 575-b (Figure 9e).
[35] Three plateau ages were also calculated for samples BF96-653, BF96-314, and BF96-318 at 5.8 $\pm 0.1,6.5 \pm 0.1$, and $7.2 \pm 0.1 \mathrm{Ma}$, respectively (Figures 10a and 10b). The hump shaped age spectrum of BF96-318 exhibits concordant apparent ages at $\sim 3.5-4 \mathrm{Ma}$ in the low and high temperatures. The youngest ages are displayed by three samples of DDH76-02 core close to the oxidation front in the pyrolusite domain. The apparent age at $\sim 3 \pm 1.3 \mathrm{Ma}$ measured for BF96-62-03 (Figure 10a) is concordant with plateau ages at $3.4 \pm 0.1\left(80.6 \%{ }^{39} \mathrm{Ar}\right.$ released $)$ 


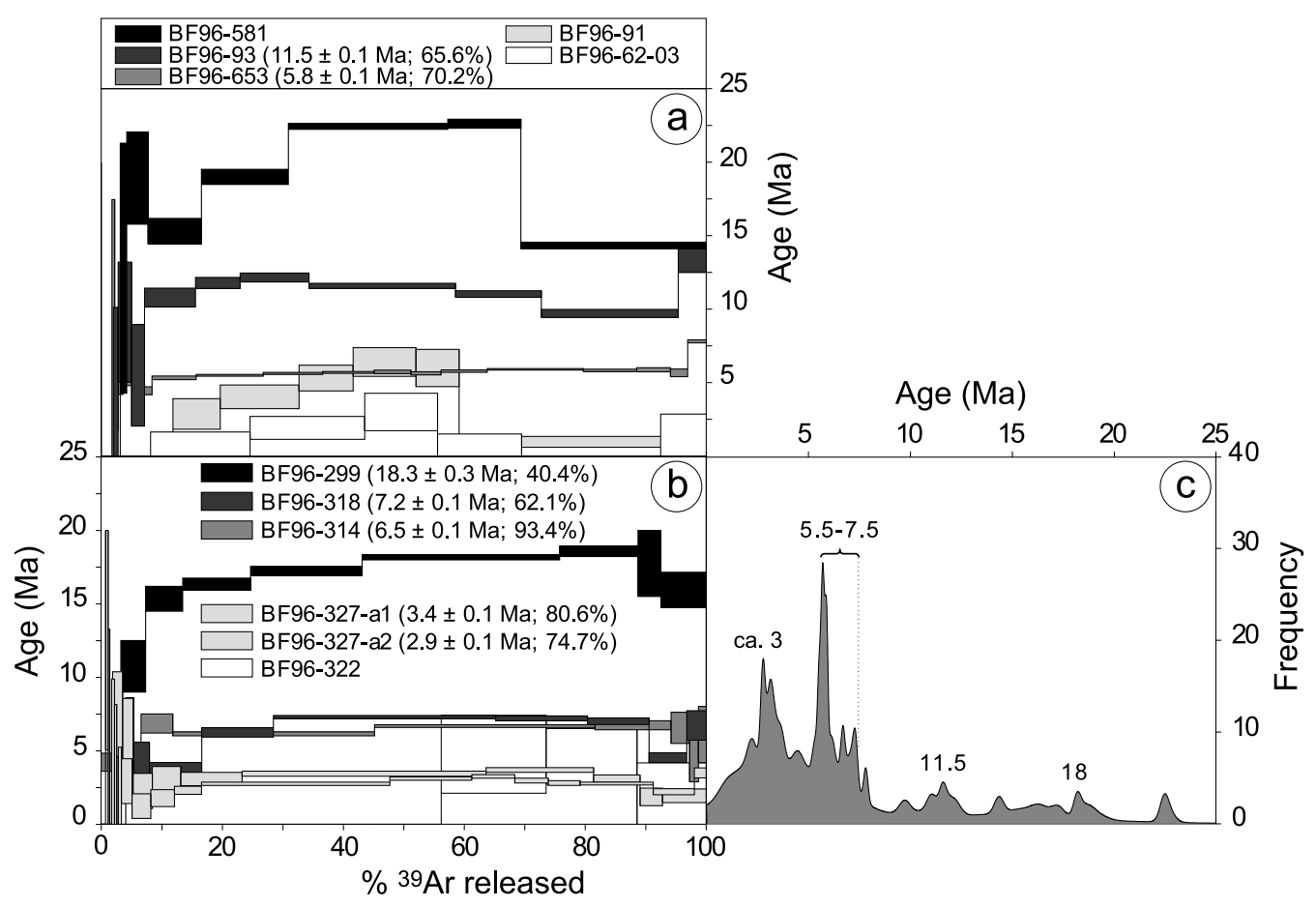

Figure 10. The ${ }^{39} \mathrm{Ar}^{40} \mathrm{Ar}$ age spectra of cyptomelane extracted from the lower part of the deposit (300-253 altitudes) for (a) samples from DD2B, DDH76-09 drill cores, and low glacis; (b) DDH76-02 drill core; and (c) frequency diagram of apparent ages. (See Figure 3 for sample locations.)

and $2.9 \pm 0.1 \mathrm{Ma}\left(74.7 \%{ }^{39}\right.$ Ar released $)$ yielded by samples BF96-327-a1 and BF96-327-a2, respectively (Figure 10b). Ages at 5.5-7.5 and $\sim 3 \mathrm{Ma}$ are well depicted by the age frequency diagram, which also reveals ages at $11.5,18$, and 22.5 Ma (Figure 10c).

\section{The ${ }^{39} \mathrm{Ar}-{ }^{40} \mathrm{Ar}$ Ages Interpretation}

[36] The oldest ages ( $\sim 59-\sim 45 \mathrm{Ma})$ obtained for cryptomelane of outcrop and surface samples (Figure 8a) are coherent with the ages of massive Mn crust and pisolites [Colin et al., 2005], and also the ages of botryoidal concretions [Hénocque et al., 1998]. These ages indicate a sustained humid and warm paleoclimate for at least $14 \mathrm{Ma}$ that could represent the duration of the Eocene bauxite formation period. The age $\sim 49$ Ma obtained for a cryptomelane at $-25 \mathrm{~m}$ depth ( $\mathrm{Col} 3$ ) allows estimation of $2.5 \mathrm{~m}$ $\mathrm{Ma}^{-1}$ for the oxidation front sinking rate between 59 and $49 \mathrm{Ma}$. However, the staircase and hump shapes of age spectra of drill core samples in the highest part of layers I, II and III suggests a reactivation of geochemical weathering process, and thus a rejuvenation of older minerals (Figure 8). Concentric banded overgrowth structures (e.g., botryoidal) effectively result from repeated geochemical mobilizations of $\mathrm{Mn}$ and $\mathrm{K}$ that led to newly formed cryptomelane generations (Figure 5c). Their crystal size is so small that handpicking sampling inevitably implied mixings of "old" and "young" generations characterized by hump-shaped age spectra, with maximum apparent ages in the range 40-33 $\mathrm{Ma}$ and lower than the plateau and pseudoplateau ages of outcrop samples (Figure 8a).

[37] The age spectra of the first group document two subsequent weathering episodes (Figure 8d). An episode at $\sim 27-23 \mathrm{Ma}$ is obviously defined in the upper part of the cryptomelane domain as shown by the diagram of plateau and pseudoplateau ages versus altitude where the elevation ranges of each lateritic landsurface are also represented (Figure 11a). This episode was also characterized in the pisolitic crust [Colin et al., 2005], where it superimposed to the lateritic episode at $\sim 46 \mathrm{Ma}$. The lower part of the cryptomelane domain also yields reproducible pseudoplateau and plateau ages in the range 29-24 Ma (Figure 9) that could document the downward propagation of the oxidation front at an average rate of $2 \mathrm{~m} \mathrm{Ma}^{-1}$. Another weathering episode is depicted by low temperature ages around 18-17 $\mathrm{Ma}$ (Figures $8 \mathrm{~b}, 8 \mathrm{c}$, and $8 \mathrm{~d}$ ). Plateau ages at $18-17 \mathrm{Ma}$ were also obtained in the lower part of the cryptomelane domain and for vein cryptomelane of the upper pyrolusite domain (Figures 9c and 10b) that further supports the likelihood of this weathering episode.

[38] The youngest ages, $\sim 18$ to $\sim 3 \mathrm{Ma}$, document active weathering and oxidation processes during the Neogene. Cryptomelane often crystallized in small veins and concretions in the pyrolusite-rich lower parts of the deposit indicating episodic deep circulations of weathering solutions. The cryptomelane crystals are characterized by plateau ages ranging between 17.8 and 2.9 $\mathrm{Ma}$ (Figure 10), and these ages are as young as samples collected close to the oxidation front (Figure 11a). Figure 11a also includes ${ }^{39} \mathrm{Ar}-{ }^{40} \mathrm{Ar}$ ages obtained by previous studies [Hénocque et al., 1998; Colin et al., 2005]. Figure 11b shows less apparent age scattering and increasing purity of analyzed parageneses with depth.

[39] Although the increasing diversity of ${ }^{39} \mathrm{Ar}-{ }^{40} \mathrm{Ar}$ ages from the bottom to the top of the Mn deposit (Figure 11b) suggests a continuous chemical weathering for $59 \mathrm{Ma}$, five 


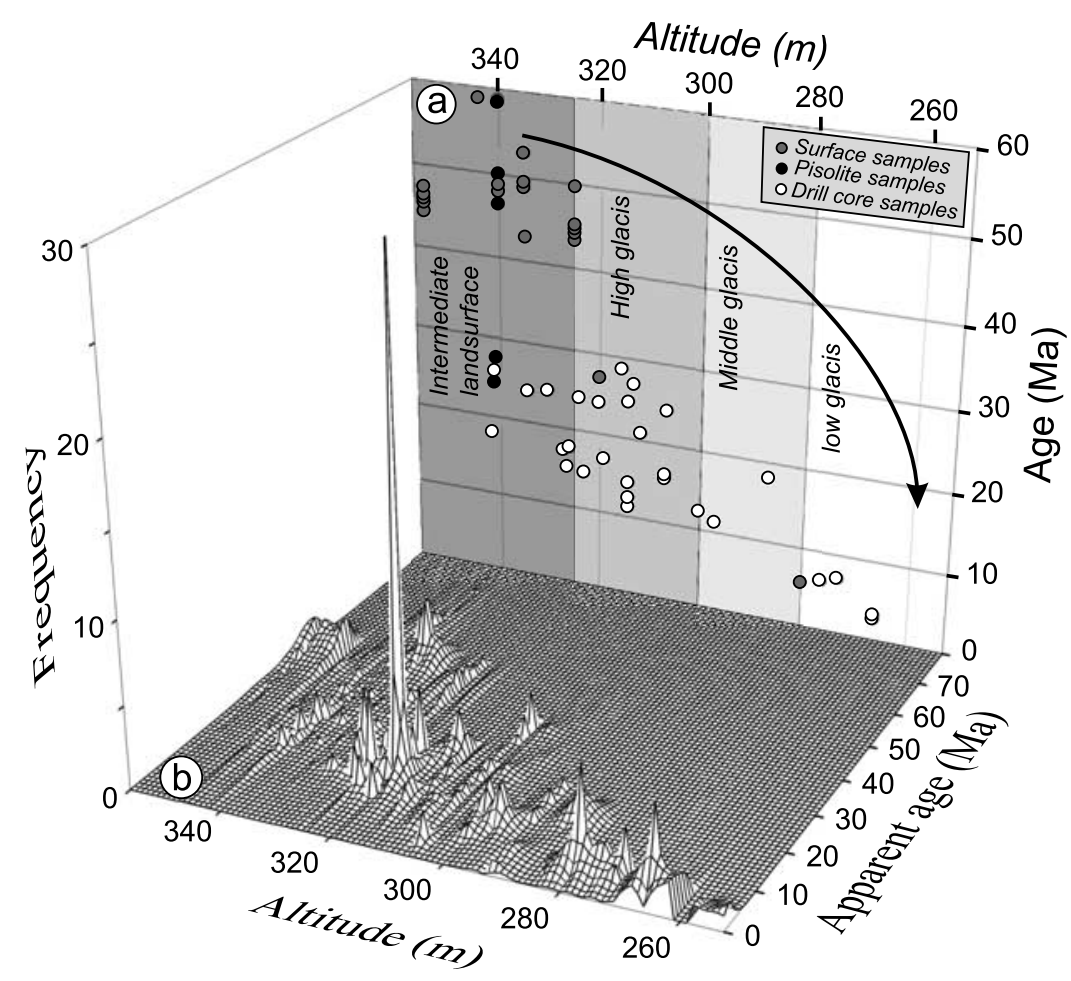

Figure 11. (a) Distribution of pseudoplateau and plateau ages as a function of altitude in the Mn deposit with the superimposition of the elevation ranges of each landsurface. (b) Three-dimensional frequency diagram of all apparent ages versus altitude. Curved black arrow indicates the decreasing chemical weathering and increasing erosion rate.

main weathering periods can be differentiated. The first from $\sim 59$ to $\sim 45$ Ma characterizes a long-weathering period, during which bauxites formed all over the tropical belt [Bardossy and Aleva, 1990]. The second occurred in the range 29-24 Ma with an occurrence at $21 \mathrm{Ma}$ (Figure 11a), and it was well depicted in the ore deposit (Figure 9). The intermediate landsurface was also deeply weathered during this major period. The three last periods are characterized by short-weathering episodes, 18-11.5, 7.2-5.8, and 3.4-2.9 Ma (Figure 11a), during which the three glacis were probably weathered along with recurrences between 18 and $11.5 \mathrm{Ma}$ in the preexisting intermediate landsurface profile (Figure 11a).

\section{Lateritic Weathering, Palaeoclimates, Long-Term Morphogenesis, and Denudation}

[40] Petrographical and geochemical patterns of the different lateritic landsurfaces and the height difference between the landsurfaces reflect differences in duration and intensity of weathering and erosion processes linked to contrasted paleoclimates between the Palaeogene and Neogene [Tardy and Roquin, 1998]. The comparison of the global $\delta^{18} \mathrm{O}$ and eustatic curves [Miller et al., 2005] with ${ }^{39} \mathrm{Ar}-{ }^{40} \mathrm{Ar}$ ages distribution (Figures 12a, 12b, and $12 \mathrm{c})$ and with the intracontinental sedimentary sequences (Figure 13a) contributes to a better understanding of the influence of Cenozoic paleoclimatic changes on West African landscapes. The age frequency histogram in Figure $12 \mathrm{c}$ incorporates all the results including those obtained from the previous studies [Hénocque et al., 1998; Colin et al., 2005]. The series of ${ }^{39} \mathrm{Ar}-{ }^{40} \mathrm{Ar}$ ages and time intervals between these ages may document, as a surrogate for long-term paleoclimatic proxies, the major chemical weathering (warm/humid climate) and mechanical erosion (cold/dry climate) periods (Figures 12 and 13b). The altitude of dated samples and the elevation (maximum) of each planation landsurface allow estimation of average mechanical erosion rate for different time spans corresponding to the successive lateritic planation cycles.

[41] From Paleocene ( $\sim 60 \mathrm{Ma})$ to middle Lutetian ( $\sim 45 \mathrm{Ma}), \delta^{18} \mathrm{O}$ is low and the eustatic level is high [Zachos et al., 2001; Miller et al., 2005] (Figure 12a and 12b). The identification of marine sediment incursions between the "Continental Intercalaire" and the basal unconformity in the Iullemmeden basin, $150 \mathrm{~km}$ north northeast and east of Tambao (Figure 13a) indicates a maximal extension of the Saharan sound between 55 and $60 \mathrm{Ma}$ in western Niger [Petters, 1977]. The marine sediments are mainly composed of carbonates, marls, and clays dominated by sepiolite, palygorskite and attapulgite [Millot, 1970; Chamley et al., 1988; Ly and Anglada, 1991] that characterize biogeochemical sedimentation. This was also linked to the genesis of thick bauxitic weathering mantles inland including a differential sequestration of $\mathrm{Fe}$ and $\mathrm{Mn}$ according to their respective chemical mobility.

[42] Bauxites have been described on Precambrian basement and also upon the unconformity (Figure 13a) between the Continental Intercalaire deposits and the siderolithic 


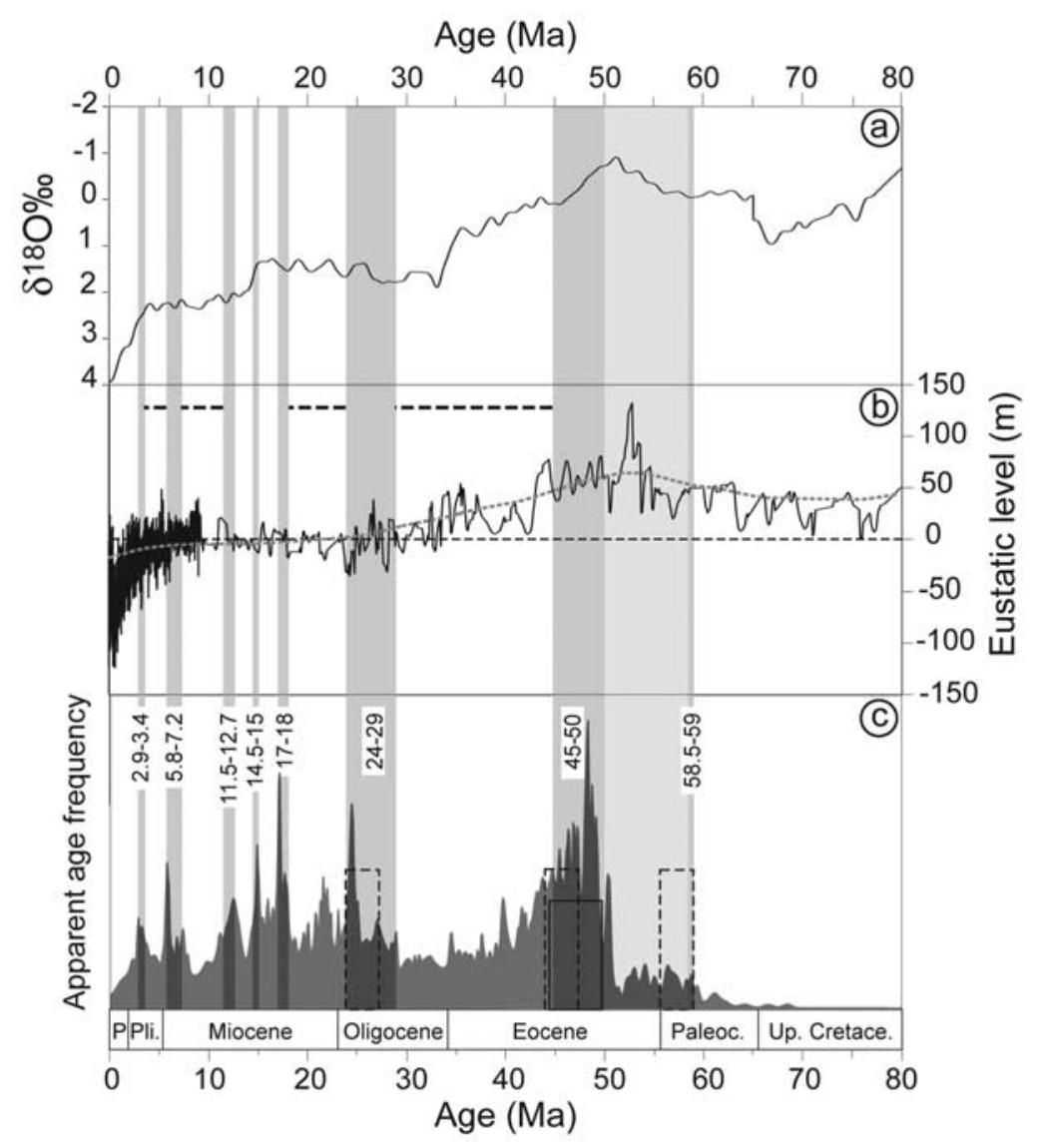

Figure 12. Comparison between the global curves of (a) $\delta^{18} \mathrm{O}$ paleotemperatures and (b) eustatic levels, both from Miller et al. [2005], with (c) ${ }^{39} \mathrm{Ar}^{40}{ }^{40}$ age groups (gray scale bands) defined by pseudoplateau or plateau ages depicted in this work. The dotted gray curve in Figure $12 \mathrm{~b}$ is the long-term fit of the sea level curve and the straight dotted black segments represent the erosion periods. The rectangle and dotted rectangles in Figure $12 \mathrm{c}$ represents the ${ }^{39} \mathrm{Ar}-{ }^{40} \mathrm{Ar}$ age groups previously obtained by Hénocque et al. [1998] and Colin et al. [2005], respectively; the dark gray histogram represents the age frequency weighted by the error margin for the deposit as a whole; and the light gray scale band represents the paroxysm of the bauxitic weathering period.

"Continental Terminal" (CT) in the Iullemmeden basin [Faure, 1966; Gavaud, 1977; Lang et al., 1990]. The basal sequence of CT (Upper Lutetian) is characterized by ooliths, which are also interstratified within the upper siderolithic sediments [Boudouresque et al., 1982]. This suggests that dissolved iron input originated from inland lateritic formations, whereas the siderolithic detrital sediments corresponds to the mechanical erosion of lateritic weathering mantles according to alternating humid and dry palaeoclimates, respectively. A ferricrete specific of the intermediate surface has also been described upon the CT sediments (Figure 13a) of Mali and Niger [Gavaud, 1977; Lang et al., 1990]. Relicts of a similar ferricrete are also present on the high hill where ${ }^{39} \mathrm{Ar}-{ }^{40} \mathrm{Ar}$ ages of $59-45$ and also 29-24 Ma were measured. The field observations and ${ }^{39} \mathrm{Ar}-{ }^{40} \mathrm{Ar}$ data imply that the bauxitic and intermediate ferruginous paleolandsurfaces intersected near the Tambao Mn deposit (Figure 13a), thus questioning the supposed Pliocene age of the ferricrete upon the CT sediments [Michel, 1973; Grandin, 1976; Gavaud, 1977].
[43] Biogeochemical sedimentation ceased in mid-Eocene (Lutetian) as indicated by the marine sedimentary gap at the bottom of Iullemmeden [Faure, 1966; Boudouresque et al., $1982]$ and Senegalese basins [ $L y, 1985]$. This gap might be correlated to the sea level drop between $\sim 34$ and $\sim 29 \mathrm{Ma}$ [Miller et al., 2005] (Figure 12b) that resulted from Oligocene global cooling concomitant with the development of East Antarctic Ice Sheet [Salamy and Zachos, 1999; Zachos et al., 2001]. These changes have induced drier climatic conditions on continents [Lawver et al., 1992], with an apogee at $\sim 33.5 \mathrm{Ma}$ [Kennett and Shackleton, 1976; Zachos et al., 1994, 1996; Salamy and Zachos, 1999; Miller et al., 2005] and a persistence until the Middle Oligocene-Early Miocene [Flower and Kennett, 1994] as indicated by $\delta^{18} \mathrm{O}$ increase [Miller et al., 2005] (Figure 12a). No significant ${ }^{39} \mathrm{Ar}-{ }^{40} \mathrm{Ar}$ ages were obtained in the range 45-29 Ma (Figure 12c). Following the eustatic change, the progressive sea retreat toward north and south [Faure, 1966] led to the incision and erosion of previous lateritic landforms. An average mechanical erosion rate of $3 \mathrm{~m} \mathrm{Ma}^{-1}$ can be calculated for the period 45-29 Ma assuming an elevation 
SW
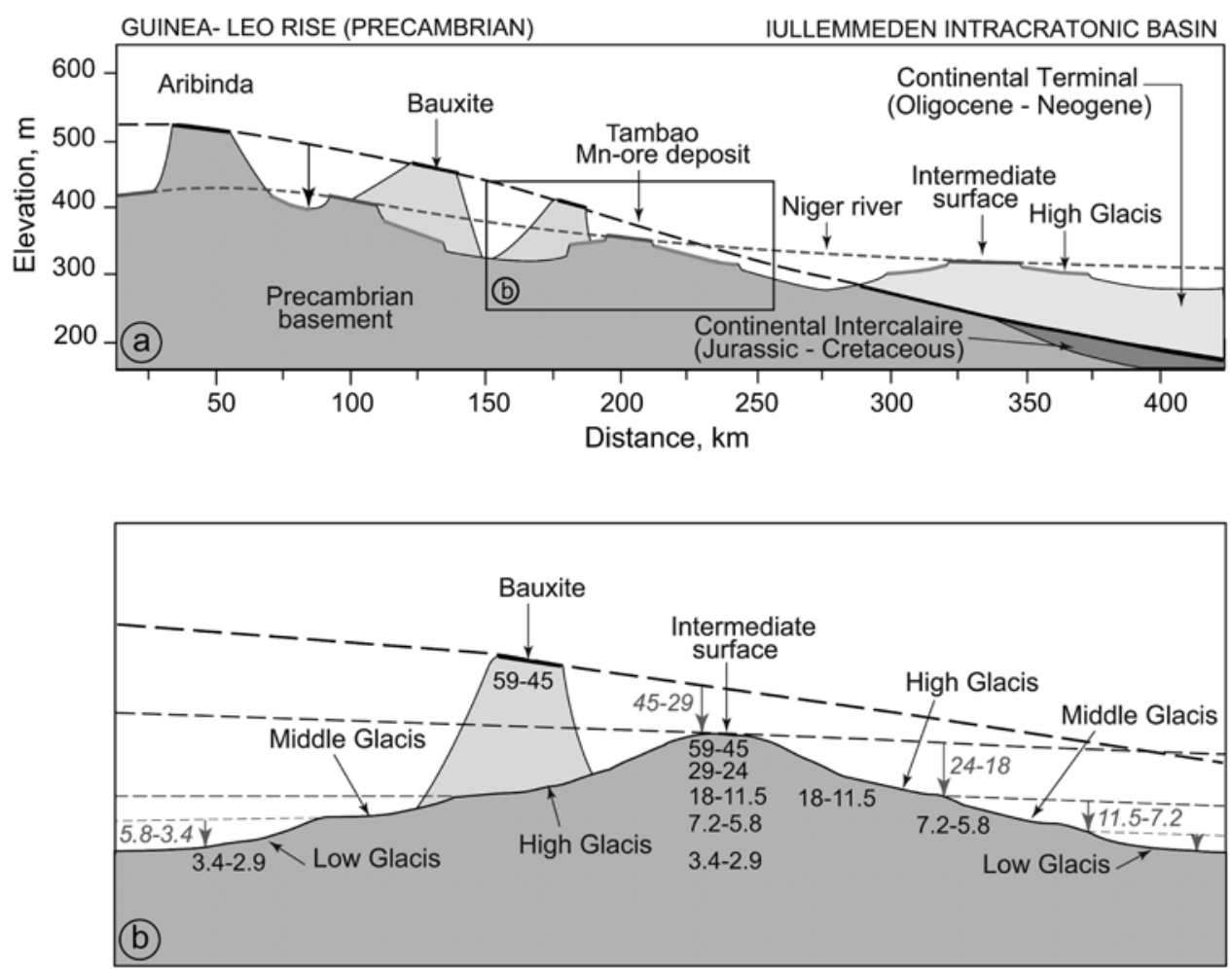

Figure 13. (a) Geomorphological relationships between the lateritic paleolandsurfaces (dotted lines) and the sedimentary sequences of the Iullemmeden basin of Niger in West Africa. The light gray trapezoids represent the denuded bauxites and the vertical black arrow represents the total denudation of the regolith. (b) Detailed morphogenetic processes around Tambao. The black numbers are the weathering periods in $\mathrm{Ma}$, the gray numbers are the erosion periods in $\mathrm{Ma}$, and the vertical gray arrows are the regolith denudation and topographic decay.

of $400 \mathrm{~m}$ for the warped bauxitic landsurface, and the intermediate surface at $350 \mathrm{~m}$ (Figure 13a). At that time, continental sedimentation (siderolithic CT) could include lateritic materials eroded from early bauxitic and clay ferruginous weathering mantles. The bauxite erosion allowed the exhumation of ferruginous materials, i.e., the formation of the ferricrete-bearing intermediate landsurface.

[44] The next major episode of chemical weathering in Tambao occurred around 29-24 Ma (Figure 12c) corresponding with late Oligocene global warming [Zachos et al., 2001] and to a relative stability of the global sea level [Miller et al., 2005]. This age interval was particularly well represented in the $\mathrm{Mn}$ ore deposit (Figure 9b) and could date the weathering of the recently exhumed intermediate lateritic profiles (Figures 11a and 13b) and also the formation of the older ferricrete observed upon the Iullemmeden CT sediments (Figure 13a).

[45] Although Milankowitch glacial-interglacial cycles are well documented in the Oligocene [Retallack et al., 2004], the global Earth climate was frankly driven by a glacial-interglacial dynamic from the boundary Oligocene/ Miocene [Zachos et al., 2001]. The three ferruginous glacis could be formed between 24 and $3 \mathrm{Ma}$ as results of the alternation of mechanical erosion and chemical weathering episodes (Figures 12 and 13b) according to low-frequency climatic oscillations but higher seasonality. Except an age at $\sim 21 \mathrm{Ma}$, the interval 24-18 Ma could have been propitious to the mechanical erosion of the intermediate landsurface at an average rate of $4 \mathrm{~m} \mathrm{Ma}^{-1}$, at least partially, and to the final denudation of bauxitic remnants. This major mechanical erosion episode led to the setting of the high glacis, which was weathered at $18-17,15-14.5$, and 12.7-11.5 Ma (Figures 11a, 12c, and 13b) as suggested by the increase of $\delta^{18} \mathrm{O}$ and the relatively high sea level [Berger and Wefer, 1996; Miller et al., 2005] (Figures 12a and 12b). Coarser lateritic materials including bauxite and ferricrete debris were also reworked into the newly formed high glacis landsurface that is characteristic of glacisforming processes under drier climatic conditions [Vogt, 1959; Michel, 1973, 1978; Grandin, 1976; Boulangé and Millot, 1988; Thomas, 1994]. Notice also that the weathering of intermediate surface remnants could have been reactivated between 18 and $11.5 \mathrm{Ma}$ (Figure 11a) confirming observations in other West African areas [Beauvais et al., 1999, 2004]. The interval 11.5-7.2 Ma would correspond to the mechanical erosion of the high glacis at an average rate of $6 \mathrm{~m} \mathrm{Ma}^{-1}$ leading to the middle glacis emplacement before it's weathering at 7.2-5.8 Ma. A short-erosive episode from $\sim 5.8$ to $3.4 \mathrm{Ma}$ at an average rate of $8 \mathrm{~m} \mathrm{Ma}^{-1}$, which is comparable with the previously estimated erosion rate using cosmogenic nuclides [Brown et al., 1994], allowed emplacement of the low 
glacis, before this latter was weathered at $\sim 3.4-2.9 \mathrm{Ma}$ (Figure 13b).

\section{Conclusion}

[46] $\mathrm{The}^{39} \mathrm{Ar}-{ }^{40} \mathrm{Ar}$ ages were obtained on different cryptomelane generations sampled on outcrops and drill cores in the Mn ore deposit of Tambao (North Burkina Faso), which mainly developed from the oxidation of carbonate and silicate protores. The ${ }^{39} \mathrm{Ar}^{40} \mathrm{Ar}$ ages were compared with the variations of the global $\delta^{18} \mathrm{O}$ and eustatic curves that documented successive Cenozoic chemical weathering and mechanical erosion periods driven by the alternation of warm/humid climates and cold/dry climates, respectively. The interval 59-45 Ma corresponds to the Eocene bauxitic period, implying that cryptomelane formed during warm and humid periods in well-oxygenated lateritic weathering profiles. However, bauxite ferruginization and thus the starting of ferricrete individualization in the profiles characterized the end of this period, $\sim 50$ to $\sim 45 \mathrm{Ma}$. The lack of significant measured ages from $\sim 45$ to $\sim 29$ Ma corresponds to a period dominated by incision and erosion processes under drier climatic conditions, during which continental sediments started to accumulate in West African intracratonic basins. The intermediate landsurface was probably formed at the end of this period ( $34-\sim 29 \mathrm{Ma})$. Then the newly exposed lateritic land surface was further weathered between 29 and $24 \mathrm{Ma}$. This age interval could also date the ferricrete upon Iullemmeden CT sediments. The high glacis could have been shaped in the interval of $24-18 \mathrm{Ma}$, weathered around 18-17, 15-14, and 12.7-11.5 Ma, and eroded between 11.5 and $7.2 \mathrm{Ma}$, an interval propitious to the settlement of the middle glacis before this one was weathered at 7.2-5.8. The lowest glacis was shaped in the interval 5.8-3.4 Ma before the last short chemical weathering episode at 3.4-2.9 Ma. Our results allow average estimations of the oxidation front sinking rate of $2.5 \mathrm{~m} \mathrm{Ma}^{-1}$ for the period $59-45 \mathrm{Ma}$ against $1.5 \mathrm{~m} \mathrm{Ma}^{-1}$ for the period 59-3 Ma. The average erosion rates of the successive lateritic land surfaces would be 3 to $8 \mathrm{~m} \mathrm{Ma}^{-1}$ for the period 59-3 Ma. However, persistence of lateritic landsurface relicts in the landscape, and old cryptomelane (59-45 Ma) in the upper part of the ore deposit, indicates low Cenozoic denudation rates, of the order of the height differences between the lateritic landsurfaces.

[47] Acknowledgments. This is a contribution of CEREGE (UMR IRD 161), with financial support from DBT-PROSE and IRD scientific programs. We specially thank Georges Grandin and Dominique Chardon for fruitful discussions. Dominique Chardon is also gratefully acknowledged for the artwork of Figure 13a.

\section{References}

Aleva, G. J. J. (1984), Lateritisation, bauxitisation and cyclic landscape development in the Guiana shield, in Bauxite: Proceedings of the 1984 Bauxite Symposium, edited by L. Jacob Jr, pp. 111-151, Soc. for Min. Metal. Explor., New York.

Bardossy, G., and G. J. J. Aleva (1990), Lateritic Bauxites, Elsevier, Amsterdam.

Beauvais, A., A. Melfi, D. Nahon, and J. J. Trescases (1987), Pétrologie du gisement latéritique manganésifère d'Azul (Brésil), Miner. Deposita, 22, 124-134, doi:10.1007/BF00204689.

Beauvais, A., M. Ritz, J.-C. Parisot, M. Dukhan, and C. Bantsimba (1999), Analysis of poorly stratified lateritic terrains overlying a granitic bedrock in West Africa, using 2D electrical resistivity tomography, Earth Planet. Sci. Lett., 173, 413-424, doi:10.1016/S0012-821X(99)00245-9.

Beauvais, A., M. Ritz, J.-C. Parisot, C. Bantsimba, and M. Dukhan (2004), Combined ERT and GPR methods for investigating two stepped lateritic weathering systems, Geoderma, 119, 121-132, doi:10.1016/j.geoderma. 2003.06.001.

Berger, W. H., and G. Wefer (1996), Expeditions into the past: Paleoceanographic studies in the south Atlantic, in The South Atlantic: Present and Past Circulation, edited by G. Wefer et al., Springer, New York.

Boudouresque, L., D. Dubois, J. Lang, and J. Trichet (1982), Contribution to the stratigraphy and paleogeography of the western edge of the Iullemmeden basin during the upper Cretaceous and Cenozoic (Niger and Mali, West Africa), Bull. Soc. Geol. Fr., 24, 685-695.

Boulangé, B., and G. Millot (1988), La distribution des bauxites sur le craton Ouest Africain, Sci. Geol. Bull., 41, 113-123.

Boulanger, J. J., and H. Sanguinetti (1970), Evaluation générale du gisement de manganèse de Tambao, Haute Volta: Enquêtes sur le développement minier dans le nord-est et facteurs associés de transport, Rapp. 3, 48 pp., U. N. Dev. Programme, Ouagadougou.

Brown, T. E., D. L. Bourlès, F. Colin, Z. Sanfo, G. M. Raisbeck, and F. Yiou (1994), The development of iron crust lateritic systems in Burkina Faso, West Africa examined with in-situ-produced cosmogenic nuclides, Earth Planet. Sci. Lett., 124, 19-33, doi:10.1016/0012-821X(94)00087-5.

Burns, R. G., and V. M. Burns (1979), Manganese oxides, in Marine Minerals, edited by P. H. Ribbe, pp. 1-46, Mineral. Soc. of Am., Washington, D. C.

Chamley, H., P. Debrabant, and R. Flicoteaux (1988), Comparative evolution of the Senegal and eastern central Atlantic basins, from mineralogical and geochemical investigations, Sedimentology, 35, 85-103, doi:10.1111/j.1365-3091.1988.tb00906.x.

Chevillotte, V., D. Chardon, A. Beauvais, P. Maurizot, and F. Colin (2006), Long-term tropical morphogenesis of New Caledonia (Southwest Pacific): Importance of positive epirogeny and climate change, Geomorphology, 81, 361-375, doi:10.1016/j.geomorph.2006.04.020.

Chukhrov, F. V., L. L. Shanin, and L. P. Yermilov (1966), Feasibility of absolute-age determination for potassium-carrying manganese minerals, Int. Geol. Rev., 8, 278-280.

Colin, F., A. Beauvais, G. Ruffet, and O. Hénocque (2005), First ${ }^{40} \mathrm{Ar} /{ }^{39} \mathrm{Ar}$ geochronology of lateritic manganiferous pisolites: Implications for the palaeogene history of a West African landscape, Earth Planet. Sci. Lett., 238, 172-188, doi:10.1016/j.eps1.2005.06.052.

Dasgupta, S., S. Roy, and M. Fukuoka (1992), Depositional models for manganese oxides and carbonates deposits of the Precambrian Sausar group, India, Econ. Geol., 87(5), 1412-1418.

Faure, H. (1966), Reconnaissance géologique des formations sédimentaires post-paléozoïques du Niger oriental, Mém. BRGM 47, Univ. of Paris, Orléans, France.

Flower, B. P., and J. P. Kennett (1994), The middle Miocene climatic transition: East Antarctic ice sheet development, deep ocean circulation and global carbon cycling, Science, 108(3/4), 537-555.

Gavaud, M. (1977), Les grands traits de la pédogenèse au Niger méridional, Trav. Doc. ORSTOM, 76, 1-102.

Grandin, G. (1976), Aplanissements cuirassés et enrichissement des gisements de manganèse dans quelques régions d'Afrique de l'Ouest, Mém. ORSTOM 82, Univ. of Strasbourg, Paris.

Gunnell, Y. (2003), Radiometric ages of laterites and constraints on longterm denudation rates in West Africa, Geology, 31(2), 131-134, doi:10.1130/0091-7613(2003)031<0131:RAOLAC>2.0.CO;2.

Hall, C. M., R. C. Walter, J. A. Westgate, and D. York (1984), Geochronology, stratigraphy and geochemistry of Cindery Tuff in Pliocene hominidbearing sediments of the middle Awash, Ethiopia, Nature, 308, 26-31, doi:10.1038/308026a0.

Hautmann, S., and H. J. Lippolt (2000), ${ }^{40} \mathrm{Ar} /{ }^{39} \mathrm{Ar}$ dating of central European K-Mn oxides a chronological framework of supergene alteration processes during the Neogene, Chem. Geol., 170(1-4), 37-80, doi:10.1016/S0009-2541(99)00241-7.

Hénocque, O., G. Ruffet, F. Colin, and G. Féraud (1998), ${ }^{40} \mathrm{Ar} /{ }^{39} \mathrm{Ar}$ dating of West African lateritic cryptomelanes, Geochim. Cosmochim. Acta, 62(16), 2739-2756, doi:10.1016/S0016-7037(98)00185-9.

Kennett, J. P., and N. J. Shackleton (1976), Oxygen isotopic evidence for the development of the psychrosphere 38 Ma ago, Science, 260, 513-515.

King, L. C. (1967), The Morphology of the Earth: A Study and Synthesis of World Scenery, 2nd ed., Olivier and Boyd, Edinburgh, Scotland.

Lang, J., et al. (1990), The continental terminal of West Africa, J. Afr. Earth Sci., 10(1-2), 79-99, doi:10.1016/0899-5362(90)90048-J.

Lawver, L. A., L. M. Gahagan, and M. F. Coffin (1992), The development of paleoseaways around Antarctica, in The Antarctic Paleoenvironment: A Perspective on Global Change, Antarct. Res. Ser., vol. 56, edited by L. P. Kennett and D. A. Warnke, pp. 7-30, AGU, Washington, D. C. 
Lippolt, H. J., and S. Hautmann (1995), ${ }^{40} \mathrm{Ar} /{ }^{39} \mathrm{Ar}$ ages of Precambrian manganese ore minerals from Sweden, India and Morocco, Miner. Deposita, 30, 246-256, doi:10.1007/BF00196360.

Ly, A. (1985), Le tertiaire de Casamance (Sénégal):Biostratigraphie (foraminifères) et sédimentologie d'après les données de subsurface, D.Sc. thesis, 215 pp., Univ. of Aix-Marseille III, Marseille, France.

Ly, A., and R. Anglada (1991), Le bassin Sénégalo-Mauritanien dans l'évolution des marges périatlantiques au tertiaire, Cah. Micropaléontol., 6(2), $23-40$.

Michel, P. (1973), Les bassins des fleuves Sénégal et Gambie: Etude géomorphologique, Mem. ORSTOM 63, Univ. of Strasbourg, Paris.

Michel, P. (1978), Cuirasses bauxitiques et ferrugineuses d'Afrique Occidentale Aperçu chronologique, Trav. Doc. Géogr. Trop., 33, 11-32.

Miller, K. G., M. A. Kominz, J. V. Browning, J. D. Wright, G. S. Mountain, M. E. Katz, P. J. Sugaman, B. S. Cramer, N. Christie-Blick, and S. F. Pekar (2005), The phanerozoic record of global sea-level change, Science, 310, 1293-1298, doi:10.1126/science.1116412.

Millot, G. (1970), Geology of Clays, Chapman and Hall, London.

Millot, G. (1983), Planation of continents by intertropical weathering and pedogenetic processes, in Lateritisation Processes: Proceedings of the International Seminar on Lateritisation Processes, edited by A. J. Melfi and A. Carvalho, pp. 53-63, A. A.. Balkema, Rotterdam, Netherlands.

Nahon, D. (1991), Introduction to the Petrology of Soils and Chemical Weathering, John Wiley, New York.

Nahon, D., A. Beauvais, P. Nziengui-Mapangou, and J. Ducloux (1984), Chemical weathering of Mn-garnets under lateritic conditions in northwest Ivory Coast (West Africa), Chem. Geol., 45, 53-71, doi:10.1016/ 0009-2541(84)90115-3

Nahon, D., B. Boulangé, and F. Colin (1992), Metallogeny of weathering: An introduction, in Weathering, Soils and Paleosols, Dev. Earth Surf. Processes Ser., vol. 2, edited by I. P. Martini and W. Chesworth, pp. 445-467, Elsevier, Amsterdam.

Oswald, J. (1992), Genesis and paragenesis of the tretravalent manganese oxides of the Australian continent, Econ. Geol., 87(5), 1237-1253.

Parc, S., D. Nahon, Y. Tardy, and P. Vieillard (1989), Estimated solubility products and field of stability for cryptomelane, nsutite, birnessite and lithiophorite based on natural lateritic weathering sequences, $\mathrm{Am}$. Mineral., 74, 466-475.

Partridge, T. C., and R. R. Maud (1987), Geomorphic evolution of Southern Africa since the Mesozoic, S. Afr. J. Geol., 90, 179-208.

Pedro, G. (1968), Distribution des principaux types d'altération chimique à la surface du globe, Rev. Geogr. Phys. Geol. Dyn., 10(5), 457-470.

Perseil, E. A., and G. Grandin (1978), Evolution minéralogique du manganèse dans trois gisements d'Afrique de l'Ouest: Mokta, Tambao, Nsuta, Miner. Deposita, 13, 295-311, doi:10.1007/BF00206565.

Petters, S. W. (1977), Ancient seaway across the Sahara, Niger. Field, 42, 23-31.

Picot, P., and R. Trinquard (1969), La manganosite (MnO) du gîte de manganèse de Tambao (Haute-Volta), Bull. Soc. Fr. Mineral. Cristallogr., 92, 500-502.

Pracejus, B., and B. R. Bolton (1992), Geochemistry of supergene manganese oxide deposits, Groote Eylandt, Australia, Econ. Geol., 87(5), $1310-1335$

Retallack, G. J., J. G. Wynn, and T. J. Fremd (2004), Glacial-interglacialscale paleoclimatic change without large ice sheets in the Oligocene of central Oregon, Geology, 32(4), 297-300, doi:10.1130/G20247.1.

Roddick, J. C. (1983), High precision intercalibration of ${ }^{40} \mathrm{Ar} /{ }^{39} \mathrm{Ar}$ standards, Geochim. Cosmochim. Acta, 47, 887-898, doi:10.1016/00167037(83)90154-0.

Roy, S. (1981), Manganese Deposits, Academic, London.

Roy, S. (1988), Manganese metallogenesis: A review, Ore Geol. Rev, 4(1-2), 155-170, doi:10.1016/0169-1368(88)90011-X.

Ruffet, G., C. Innocent, A. Michard, G. Féraud, A. Beauvais, D. Nahon, and B. Hamelin (1996), A geochronological ${ }^{40} \mathrm{Ar} /{ }^{39} \mathrm{Ar}$ and ${ }^{87} \mathrm{Rb} /{ }^{87} \mathrm{Sr}$ study of K-Mn oxides from the weathering sequence of Azul (Brazil), Geochim. Cosmochim. Acta, 60, 2219-2232, doi:10.1016/00167037(96)00080-4

Salamy, K. A., and J. C. Zachos (1999), Latest Eocene-Early Oligocene climate change and Southern Ocean fertility: Inferences from sediment accumulation and stable isotope data, Palaeogeogr. Palaeoclimatol. Palaeoecol., 145, 61-77.

Segev, A., L. Halicz, B. Lang, and G. Steinitz (1991), K-Ar dating of manganese minerals from the Eisenbach region, Black Forest, southwest Germany, Schweiz. Mineral. Petrogr. Mitt., 71, 101-114.

Tardy, Y., and C. Roquin (1998), Dérive des Continents, Paléoclimats et Altérations Tropicales, Bur. de Rech. Géol. et Min., Orléans, France.

Thomas, M. F. (1994), Geomoprhology in the Tropics: A Study of Weathering and Denudation in Low Latitudes, John Wiley, New York.

Turner, G. (1971), ${ }^{40} \mathrm{Ar}-{ }^{39} \mathrm{Ar}$ ages from the lunar maria, Earth Planet. Sci. Lett., 11, 169-191, doi:10.1016/0012-821X(71)90161-0.

Turner, G., and P. H. Cadogan (1974), Possible effects of ${ }^{39} \mathrm{Ar}$ recoil in ${ }^{40} \mathrm{Ar}-{ }^{39}$ Ar dating, Proc. Fifth Lunar Sci. Conf., 2, 1601-1615.

Turner, S., and P. R. Buseck (1979), Manganese oxide tunnel structures and their intergrowths, Science, 203, 456-458, doi:10.1126/science. 203.4379 .456

Varentsov, I. M. (1996), Manganese Ores of Supergene Zone: Geochemistry of Formation, Kluwer Acad., Dordrecht, Netherlands.

Varentsov, I. M., and D. I. Golovin (1987), Groote Eylandt manganese deposit, North Australia: K-Ar age of cryptomelane ores and aspects of genesis, Rep. Acad. Sci. USSR, 294(1), 203-207.

Vasconcelos, P. M. (1999), K-Ar and ${ }^{40} \mathrm{Ar}{ }^{39} \mathrm{Ar}$ geochronology of weathering processes, Annu. Rev. Earth Planet. Sci., 27, 183-229, doi:10.1146/annurev.earth.27.1.183

Vasconcelos, P. M., T. A. Becker, P. R. Renne, and G. H. Brimhall (1992), Age and duration of weathering by ${ }^{40} \mathrm{~K}-{ }^{40} \mathrm{Ar}$ and ${ }^{40} \mathrm{Ar} /{ }^{39} \mathrm{Ar}$ analysis of potassium-manganese oxides, Science, 258, 451-455, doi:10.1126/ science. 258.5081 .451

Vasconcelos, P. M., P. R. Renne, G. H. Brimhall, and T. A. Becker (1994), Direct dating of weathering phenomena by ${ }^{40} \mathrm{Ar} /{ }^{39} \mathrm{Ar}$ and $\mathrm{K}-\mathrm{Ar}$ analysis of supergene K-Mn oxides, Geochim. Cosmochim. Acta, 58, 1635-1665, doi:10.1016/0016-7037(94)90565-7.

Vasconcelos, P. M., P. R. Renne, T. A. Becker, and H. R. Wenk (1995), Mechanisms and kinetics of atmospheric, radiogenic, and nucleogenic argon release from cryptomelane during ${ }^{40} \mathrm{Ar} /{ }^{39} \mathrm{Ar}$ analysis, Geochim. Cosmochim. Acta, 59(10), 2057-2070, doi:10.1016/0016-7037 (95)00126-3.

Vogt, J. (1959), Aspects de l'évolution géomorphologique récente de l'Ouest Africain, Ann. Géogr. Fr., 68(367), 193-206.

Wijbrans, J. R., M. S. Pringle, A. A. P. Koppers, and R. Scheveers (1995), Argon geochronology of small samples using the Vulkaan argon laser probe, Proc. Kon. Akad. Wetensch. Amsterdam, 98(2), 185-218.

Yashvili, L. P., and R. K. Gukasyan (1974), Use of cryptomelane for potassium-argon dating of manganese ore of the Sevkar-Sargyukh deposit, Armenia, Dokl. Earth Sci., 212, 49-51.

Zachos, J. C., L. D. Stott, and K. C. Lohmann (1994), Evolution of early Cenozoic marine temperatures, Paleoceanography, 9(2), 353-387, doi:10.1029/93PA03266.

Zachos, J. C., T. M. Quinn, and K. A. Salamy (1996), High-resolution (104 years) deep-sea foraminiferal stable isotope records of the EoceneOligocene climate transition, Paleoceanography, 11(3), 251-266, doi:10.1029/96PA00571.

Zachos, J. C., M. Pagani, L. Sloan, E. Thomas, and K. Billups (2001), Trends, rhythms, and aberrations in global climate 65 Ma to present, Science, 292, 686-693, doi:10.1126/science.1059412.

Zartman, R. E. (1964), A geochronological study of the Love Grove Pluton from the Llano uplift, Texas, J. Petrol., 5, 359-408.

A. Beauvais and O. Hénocque, Centre Européen de Recherche et d'Enseignement de Géosciences de l'Environnement, Université AixMarseille, CNRS, INSU, IRD, Collège de France, BP 80, F-13545 Aix-enProvence CEDEX 4, France. (beauvais@cerege.fr)

F. Colin, Institut de Recherche pour le Développement, BP A5, F-98848 Nouméa, Nouvelle-Calédonie.

G. Ruffet, Géosciences Rennes, Université de Rennes 1, CNRS, CAREN, F-35042 Rennes, France. 